\title{
دور الإرشاد المهني في تأهيل ضعيفات السمع لسوق العمل في مدينة جدة
}

\author{
أ/ أربا عبد المعين زيني \\ أستاذ التربية الخاصة المشارك \\ قسم التربية الخاصة- كلية الدراسات العليا التربوية \\ جامعة الملك عبد العزيز - المملكة العربية السعودية
}

د.لينا بنت عمر بن صديق

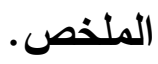

هدفت الدراسة الحالية إلى التعرف على دورالإرشاد المهني في تأهيل

ضعيفات السمع لسوق العمل في مدينة جدة، وعلى مستوى رضاهن عن دور

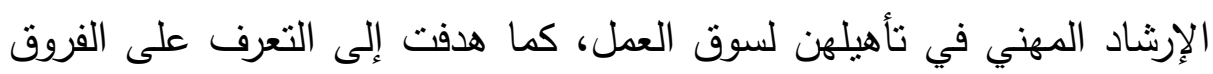
في مستوى رضا الطالبات ضعيفات السمع عن خدمات الإرشاد المهني لتأهيلهن لسوق العمل في مدينة جدة تبعًا لمتغيرالتخصص الجامعي. وقد تكونت عينة

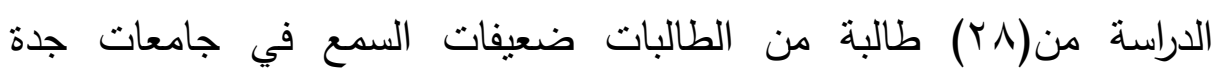
الحكومية، وقد تمّ اختيار عينة الدراسة قصديًا، واتبعت الباحثتان المنهج المسحي الوصفي؛ حيث قامتا بإعداد مقياس واقع الإرشاد المهني. وقد توصلت نتائج الدراسة إلى:أن المتوسط الحسابي لاستجابات أفراد العينة على محور "واقع الإنمادئ الإرشاد المهني في تأهيل ضعيفات السمع لسوق العمل في مدينة جدة" ومحور

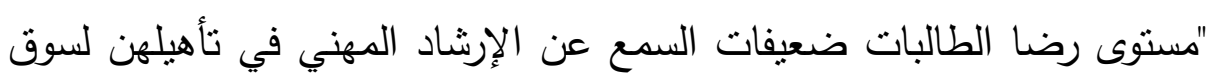

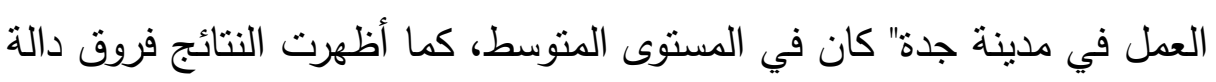
احصائياً في مستوى رضا الطالبات ضعيفات السمع عن خدمات الارشاد المهني فئي لتأهيلهن لسوق العمل في مدينة جدة تبعًا لمتغير التخصص الجامعي لصالح 


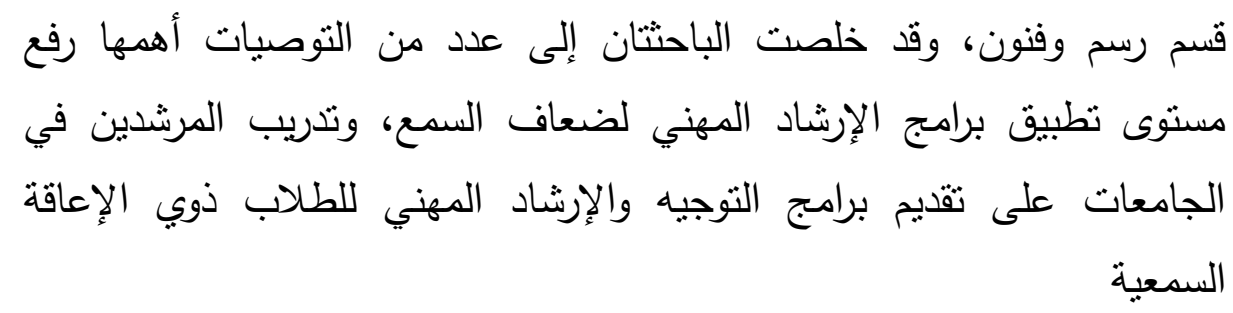

الكلمات المفتاحية: الإرشاد المهني- تأهيل- ضعيفات السمع - سوق العمل

\author{
The Role of Vocational Counseling in the Rehabilitation of the \\ Hearing Impaired Students to the Labor Market in Jeddah City \\ Dr. Lina Omar bin Siddiq \\ Ruba Abdulmoeen Zaini
}

\begin{abstract}
:
The current study aimed to identify the role of vocational counseling in the rehabilitation of the hearing impaired students to the labor market in Jeddah, it also aimed to identify the reality of vocational counseling in the rehabilitation of the hearing impaired students to the labor market in Jeddah, identify the satisfaction of the hearing impaired students about the role of vocational counseling in their rehabilitation to the labor market, and the differences in the level of satisfaction of the hearing impaired students about vocational counseling services to their rehabilitation to the labor market in Jeddah according to the different academic specialization. To achieve that, the researcher used the descriptive survey approach, Where she prepared the vocational Counseling Scale. The study reached several results, the most important of which are: that the arithmetic average of the responses of the sample members on the axis of "the reality of vocational counseling in the rehabilitation of the hearing impaired students to the labor market in the city of Jeddah" ranges from the intermediate level, the results also showed that the arithmetic average of the responses of the sample members on the axis "the satisfaction of the hearing impaired students about the vocational counseling in their rehabilitation to the labor market in Jeddah" ranges from the intermediate level, while there are statistically significant differences in the level of satisfaction of the hearing impaired students about vocational counseling services to their
\end{abstract}


rehabilitation to the labor market in Jeddah according to the different academic specialization in favor of the Department of Drawing and Arts. The researcher has reached a number of recommendations, the most important of which are : to raise the level of application of vocational counseling programs for people with disabilities, to train academic advisors to provide vocational guidance and counseling programs for persons with disabilities, In addition to conduct many studies and research related to vocational counseling for persons with disabilities in general, and the hearing impaired persons in particular.

\section{مقدمة}

للمهنة أثرًا كبيرًا في حياة الأفراد؛ فهي تُعبّرِ عن أسلوب حياة الفرد،وتُوضِّح تأثير مواقف العمل في تشكيل أنماط الأبنية النفسية لدى أعضاء المجتمع، وتحقق أغراضًا اقتصادية ونفسية واجتماعية. فمن الناحية الاقتصادية،إذا ما وُضِع الفرد في وظيفة مناسبة؛ فإن ذلك يؤدي إلى زيادة الإنتاجية. ومن الناحية النفسية، يؤدي فثنل الفرد في مهنة ما إلى شعوره بالنقص، والفشل، والإحباط، والاضطراب، والتوتز . أما اجتماعيًا، فإن البطالة عند الفرد تؤدي إلى التعرض لكثثر من مظاهرعدم التوافق النفسي والاجتماعي،فضلًا عن الضغوط النفسية التي يتعرض لها العاطلون عن العمل أكثر من غيرهم (الحوارنة، ع ا ـ ب).

وقد ذكر أبو شعيرة (11 (1) أن نسبة البطالة بين الأشخاص ذوبي

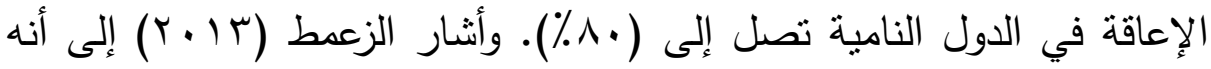
عندما تكون هناك صعوبات في إيجاد فرص عمل للمواطنين من الأشخاص إلى إلى إلى ذوي الإعاقة، والأشخاص من غير ذوي الإعاقة في بلد ما، فإن الأشخاص ذوي الإعاقة يعانون من ذلك أكثر من غيرهم. فعلى صعيد الدول الصناعية في هذه

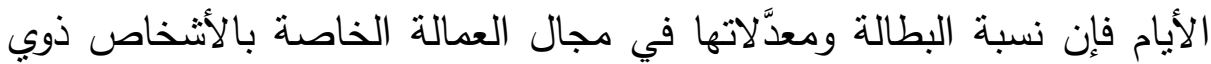


الإعاقة تعتبر ضعف معدل البطالة في مجال العمالة الخاصة بغير الأشخاص

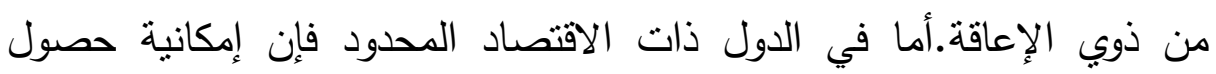
الأشخاص ذوي الإعاقة على عمل مناسب لهم في سوق العمل المفتوحة تعتبر فرص ضئيلة أو معدومة.

كما يتفق معه القربوتي(0 . ‥ في أن نسبة البطالة بين الأشخاص ذوي الإعاقة تتجاوز بكثثير نسبة البطالة بين أقرانهم من غير ذوي الاعاقة. وقلة

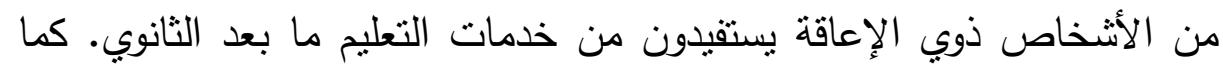
أنه نظرًا للصعوبات التي يواجهونها وعوامل أخرى؛ فإن الخبرات المتاحة لهم الإنها. وتتوعها أقل من تلك المتاحة لأقرانهم.

وهناك عدة أسباب تجعل الطلاب ذوي الإعاقة أكثرعرضة للبطالة من غيرهم منها: نقص الوعي المهني، وعدم وجود عمليات استكثاف وظيفي في وقت مبكر، ونقص التمويل لدعم خدمات التأهيل المهني، والفهم غير الواضح

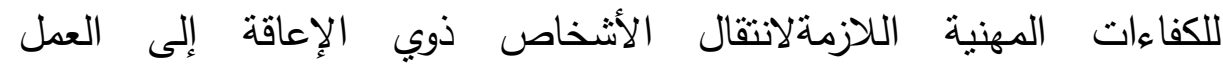
(Herbert,Trusty\& Lorenz,,$\cdot 1 \cdot$ )

تُعتبر فئة الإعاقة السمعية إحدى فئات المجتمع المهمة، والتي يمكنها المساهمة والمشاركة في عملية البناء الاقتصادي والاجتماعي للدولة إذا أُحسن دمجها والتعامل بإيجابية معها. ولعل من أهم منطلبات هذا الاندماج وتحويل هذه الفئة إلى قوة فاعلة هو تزويدهم بخدمات التأهيل المهني الذي يركز على بلى القدرات وينميها، ويزود الثخص ذو الإعاقة بالمهارات اللازمة للاندماج في

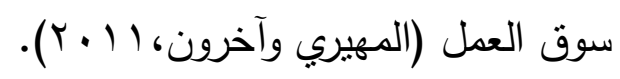




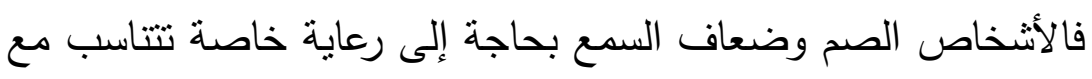

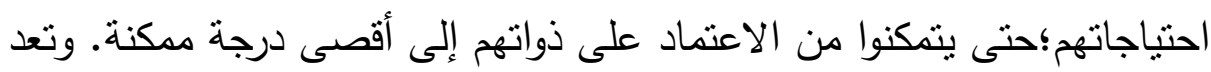

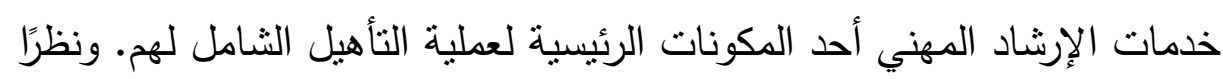

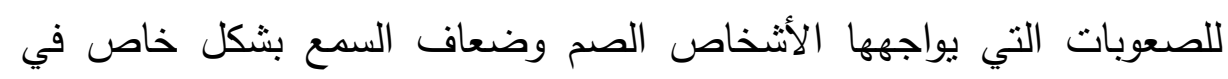
المجال المهني؛ فإن الأمر يتطلب الاهتمام بخدمات الإرشاد المهني، وتأهيلهم

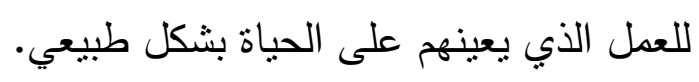

وتأني الحاجة إلى الإرشاد المهني من خلال نتوع الفروق الفردية، وتتوع

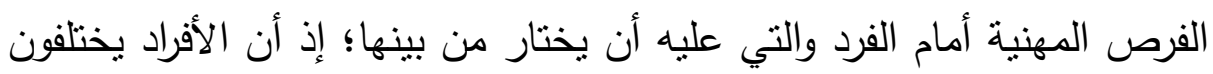
فيما بينهم من حيث القدرات، والاستعدادات، والميول، وخصائص الثخصية.

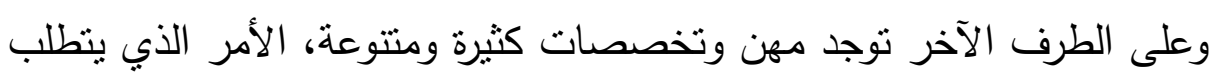

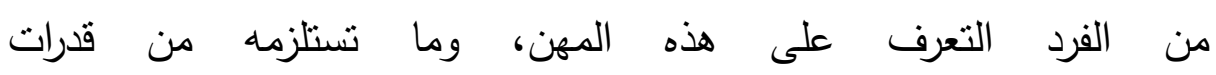

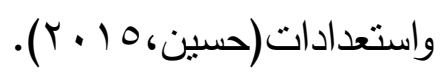

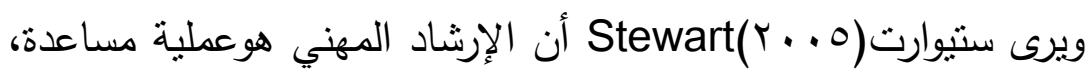

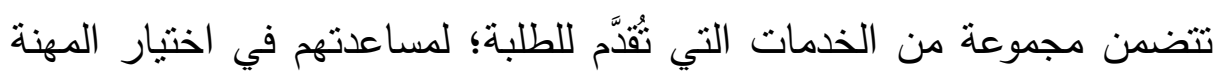

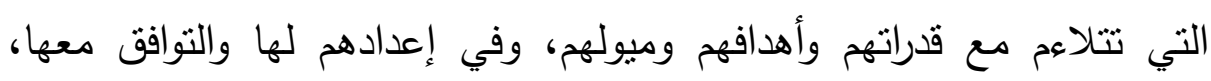

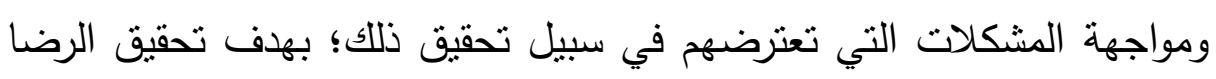
المهني، والثوافق النفسي والاجتماعي، والكفاية الإنتاجية.

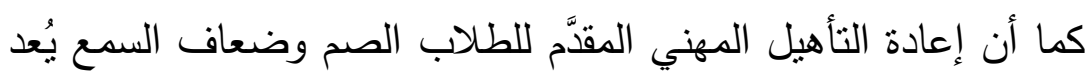

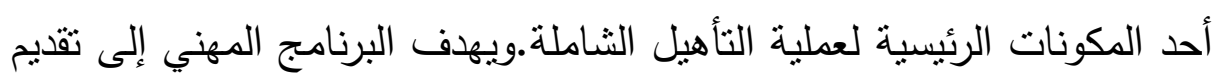

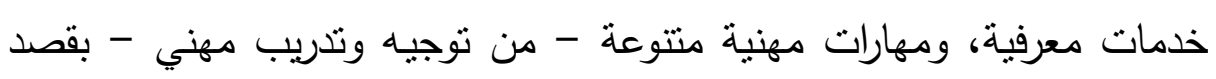

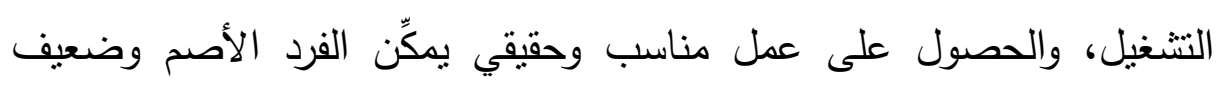


السمع من أن يحتفظ به، ويرتقي فيه، وذلك بعد تخرجه من المؤسسة

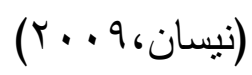

ومن هذا المنطلق جاءت الدراسة الحالية لنُسلّطُ الضوء على دور

الإرشاد المهني لضعاف السمع:وذللك لمساعدتهم في اختيار ما يناسب قدراتهم

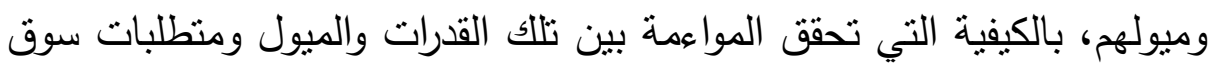

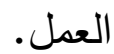

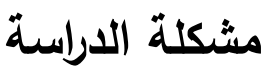

تواجه النساء ذوات الإعاقة صعوبات في التدريب الهني والتشغيل؛ حيث أن تأثير الإعاقة عليهن يبدو أكثر وضوحًا، ولعدم تكافؤ الفرص أمامهن في الفي الفيات

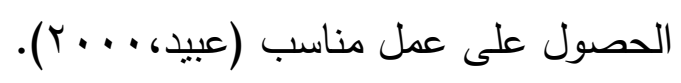

إن انخاذ القرار المهني يُشْكّل محورًا أساسيًا في مستقبل الثخص ذي الثي

الإعاقة، حيث أن الوظيفة لا تتوقف على الآمال والتطلعات والرغبات فقط؛ بل

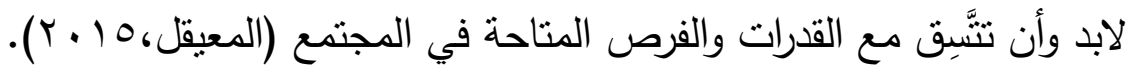

فإذا كان الطالب من غير ذوي الإعاقة يواجه الكثير من الصعوبات، فمّّا لا شك فيه أن يواجه الطالب ذو الإعاقة صعوبات وتحديات إضافية، الإنة

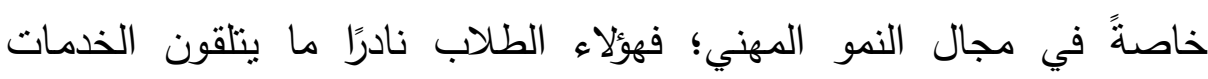
الإرشادية المهنية الداعمة على الوجه الدطلوب (الدحادحه،م. . ب).

علاوة على ذللك ذكرت نبسان(9.?) أن أكبر العقبات التي تواجه

خدمات الثأهيل المهني هي نقص الموظفَّين المُدرَبِين. كما أنّ المؤسسات

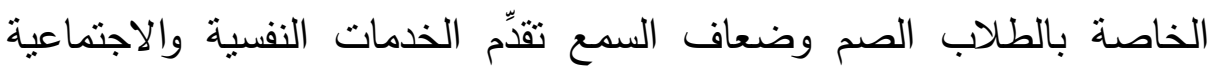

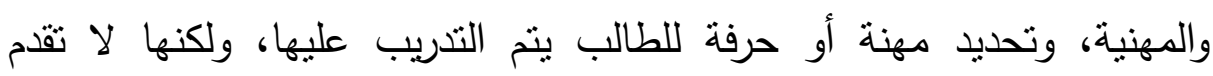


خدمات التثغيل، أو يُترك التتغيل المفتوح أو المحمي من خلال ورش خاصة بتشغيل الأثخاص ذوبي الإعاقة فقط.

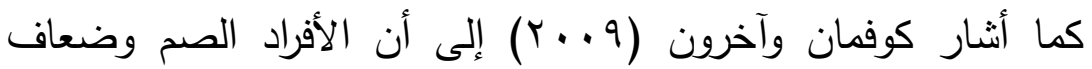
السمع يعانون من صعوبات في إيجاد وظائف مناسبة لهم؛ بسبب المعتقدات

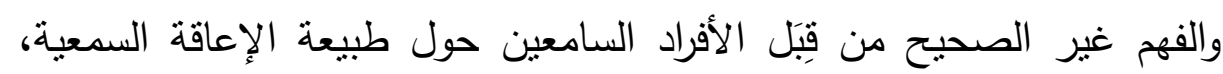

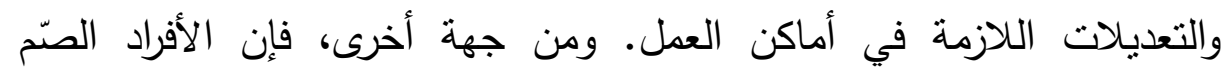

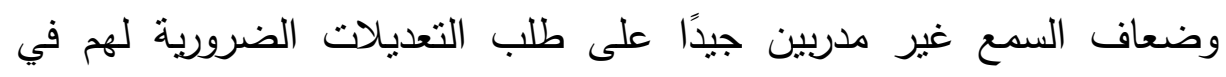

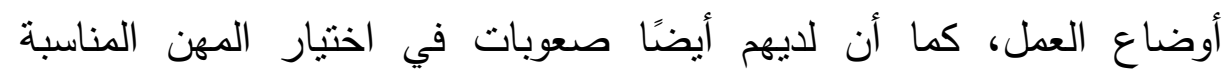

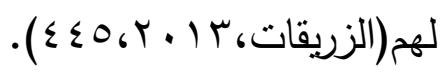

إن العديد من الثباب ذوي الإعاقة بعد التعليم الثانوي لديهم معرفة قليلة

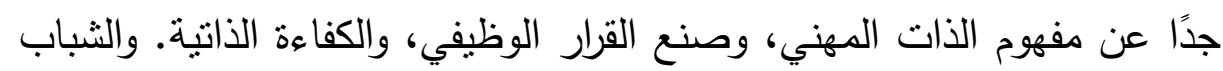

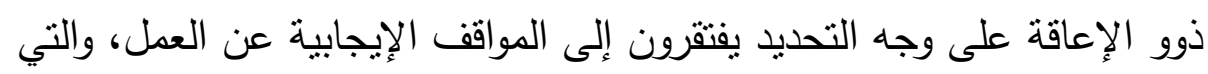

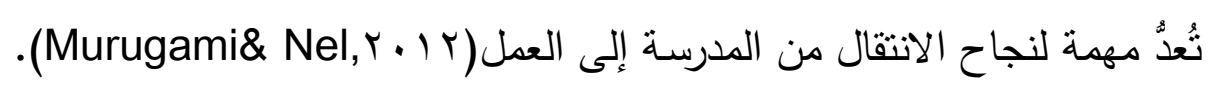
وينَِّّح ذلك من خلال ما أثنارت إليه نتائج الدراسات الني بحثت في

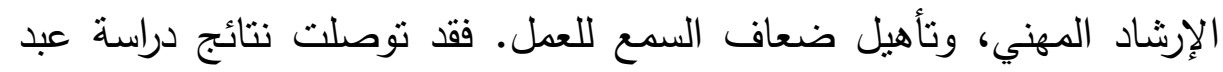

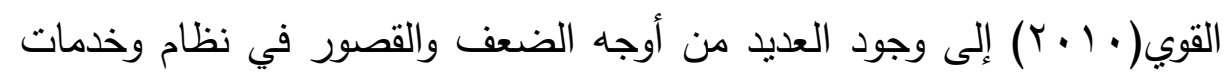

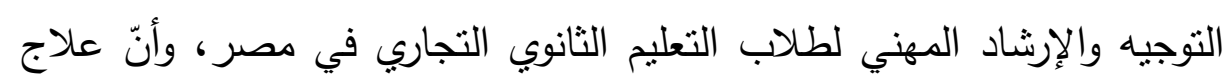

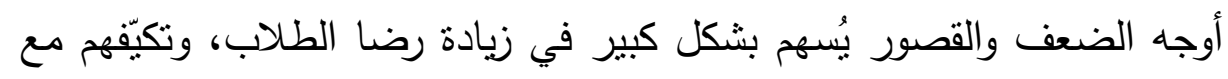
تخصصاتهم، وتتمية دوافعهم نحو التعلم، والحد من مشكلة البطالة بينهم.

وأثنارت نتائج دراسة المهيري وآخرون(1) (1) إلى أنّ أهم المشكلات

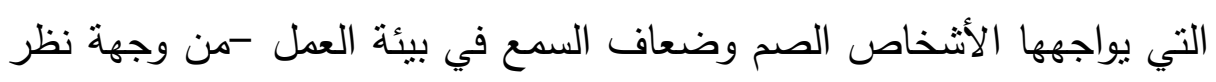


أصحاب العمل- صعوبة التواصل مع الزملاء، وصعوبة فهم التعليمات الثنفوية

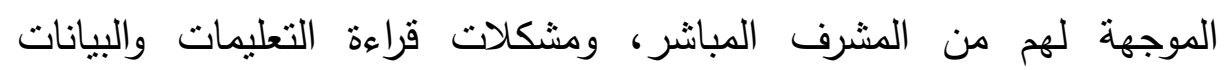

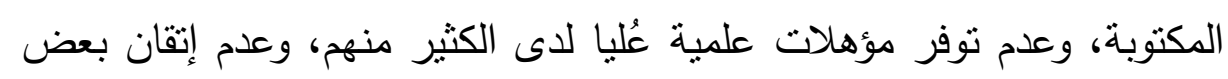

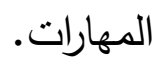

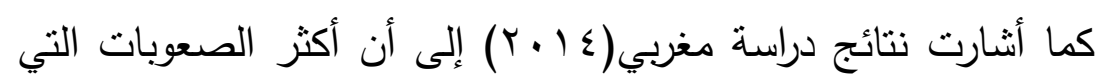

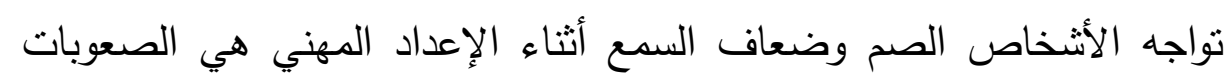

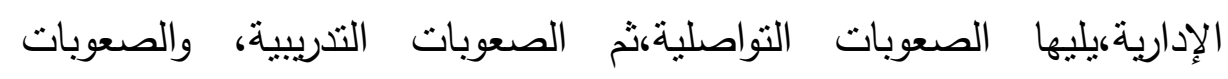
الأكاديمية،بينما أقل الصعوبات في الدرجة هي الصعوبات السلوكية الانفعالية.

حيث أن دمج الثخص ذو الإعاقة بسوق العمل،وإبعاده عن الانعزالية

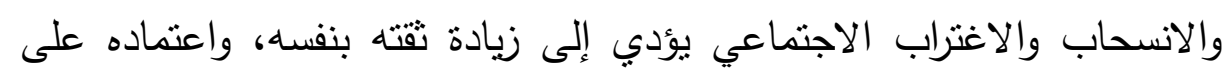

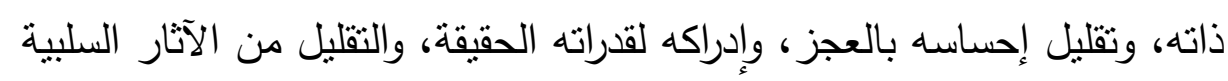

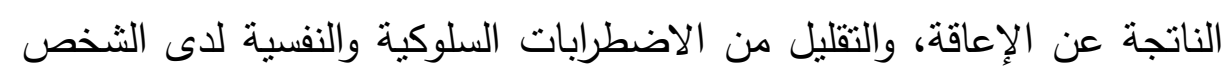

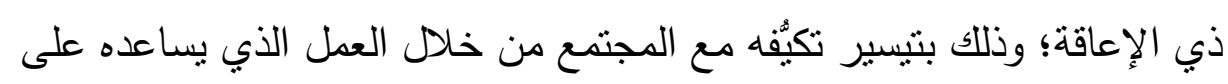

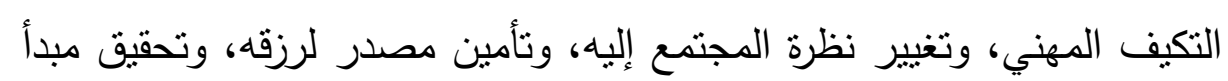

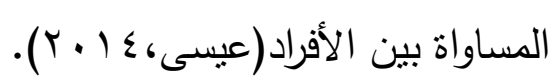

وعلى ذلك بمكن أن تتحدد مثكلة الدراسة الحالية في السؤال الرئيس التالي: ما

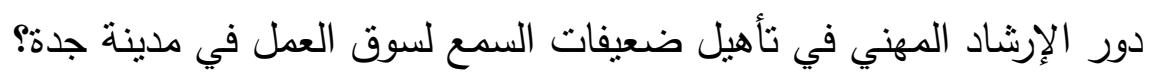

ويتفرع عن السؤال السابق الأسئلة الفرعية التالية:

1-ما واقع الإرشاد المهني في تأهيل الطالبات ضعيفات السمع لسوق العمل في مدينة جدة؟ الإنداد العن 
ץ- ما مستوى رضا الطالبات ضعيفات السمع عن دور الإرشاد الهني في

$$
\text { تأهيلهن لسوق العمل في مدينة جدة؛ }
$$

ז-هل توجد فروق دالة إحصائيًا في مستوى رضا الطالبات ضعيفات

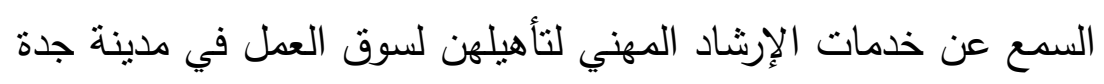

$$
\text { باختلاف التخصص الجامعي؟ }
$$

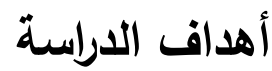

$$
\text { هدفت الدراسة الحالية إلى التعرف على: الإنى }
$$

1- دور الإرشاد المهني في تأهيل ضعيفات السمع لسوق العندف العمل في مدينة جدة.

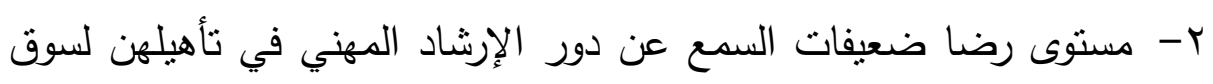

$$
\text { العمل في مدينة جدة. }
$$

r- الفروق في مستوى رضا الطالبات ضعيفات السمع عن خدمات الإرشاد

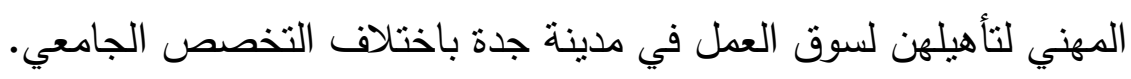

\section{أهمية الدراسة \\ تتحدد أهمية الدراسة في ناحيتين هما:

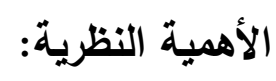

أ- تعتبر الدراسة الحالية إضافة جديدة في مجال البحث العلمي فيما يخص

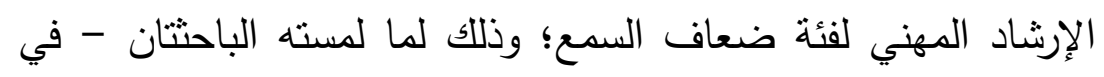

حد علمهما - من ندرة وجود دراسات عربية في هذا المجال.

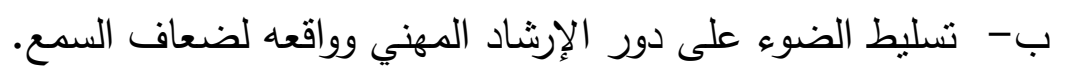


ت- فتح المجال لزيادة الدراسات العربية التي تتتاول الإششاد المهني

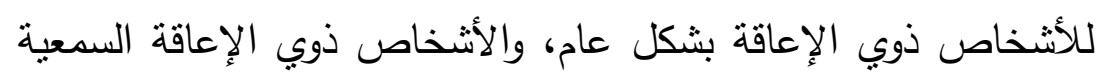
بثكل خاص. ث- - التعرف على نوعية الخدمات المهنية المقدَّمة للأشخاص ذوي الإعاقة السمعية. ج- التعرف على أبرز المعوقات التي نواجه تقديم خدمات الإرشاد المهني للطلاب ذوي الإعاقة

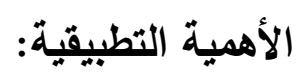

أ- تطوير خدمات الإرشاد المهني من خلال تقديم برامج تدريبية، ودورات ثُأهّّل الأشخاص ضعاف السمع لسوق العمل، وتقلل نسبة البطالة بينهم.

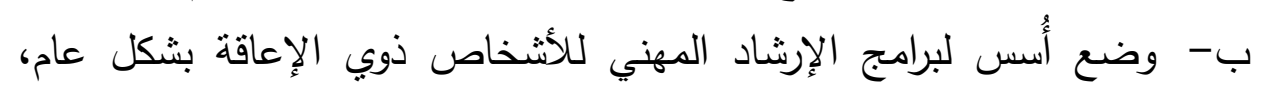
والإعاقة السمعية بشكل خاص. ت- - إعداد مقياس لاسنطلاع واقع الإرشاد المهني في تأهيل ضعيفات السمع بأس لسوق العمل.

\section{مصطلحات الدراسة}

\section{1-الإرشاد المهني (Vocational Counseling):}

يُعرّف الإرشاد المهني بأنه "مساعدة الفرد على اختيار المهنة التي

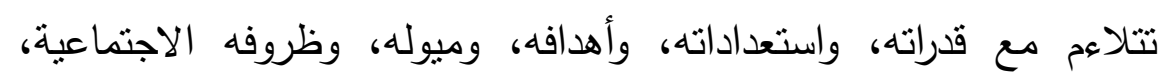

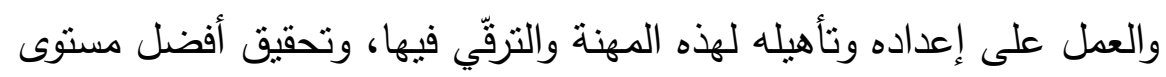

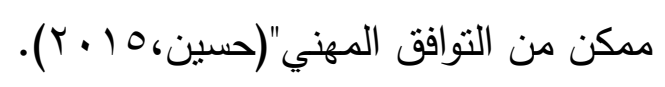




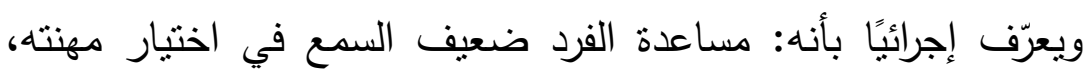
والاستعداد لها، والعمل بها، والنجاح فيها، وفقًا لقدراته وصفاته الثخصية، وكفاياته المهنية، ومنطلبات سوق العمل. وتحدد الباحثتان دور الإششاد

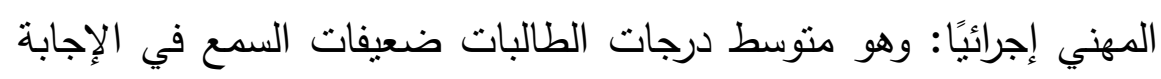
على فقرات مقياس واقع الإرشاد المهني. r- بأنأهيل (Habilitation):

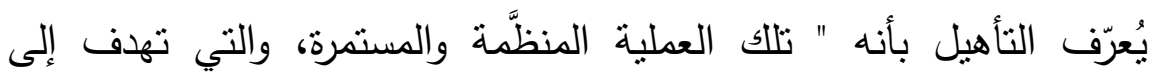

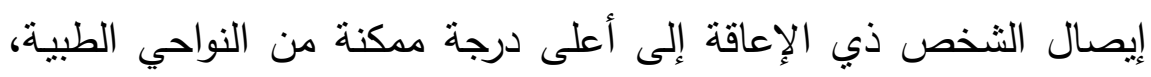

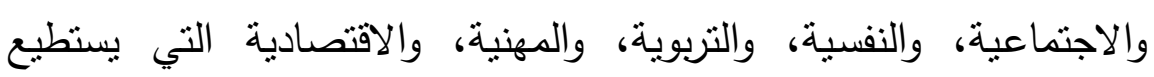

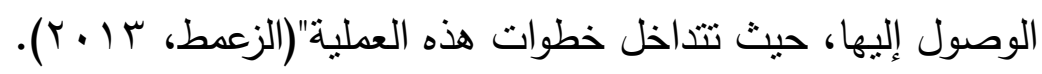

ويعرف إجرائًا بأنه: تأهيل ضعاف السمع مهنيًا من خلال تقديم برامج ودورات تدريبية في تطوير الذات والتطوير المهني والتطوير الإداري،

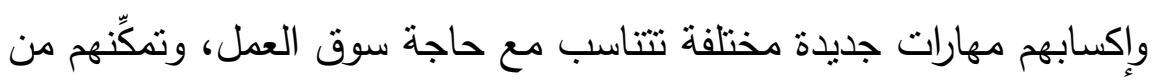
الإنتاج في العمل، والاكتقاء الذاتي إلى أقصى درجة مدكنة.

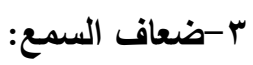

" هم الأشخاص الذين لديهم بقايا سمعية كافية تمكنهم من خلال

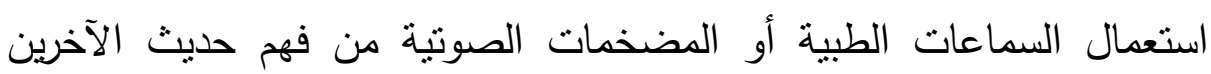

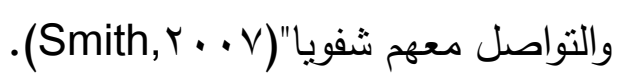

أما التعريف الإجرائي فهن: الطالبات ضعيفات السمع اللاتي يتزاوح

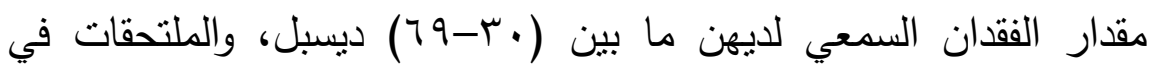

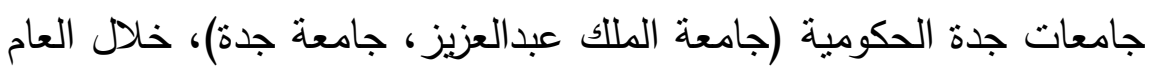

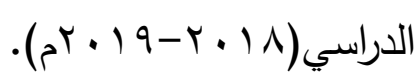




\section{حدود الدراسة}

تمثلت الحدود الموضوعية للدراسـة في قياس واقع الإرشاد المهني لتأهيل جميع الطالبـات ضـعيفات السمع لسوق العمل اللاتتي يتراوح مقدار الفقدان السمعي لإني

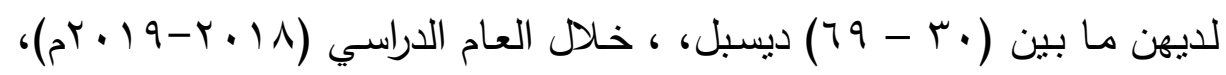
لسوق العمل، حيث تمنلث الحدود المكانية في تطبيق الدراسـة على الملتحقات في الجامعات الحكومية (جامعة الملك عبدالعزيز، جامعة جدة) بمدينة جدة، في

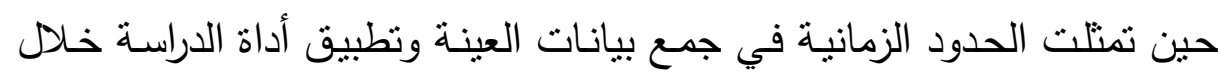

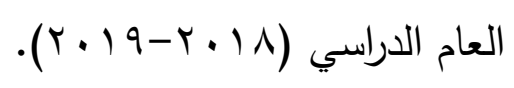

\section{الإطار النظري للإسة}

يعتبر الإرشاد المهني من أقدم مجالات الإششاد النفسي، ويرجع الفضل

إلى بارسونز (Parsons) في ظهوره، وقد بدأ حين ظهرت الحاجة إلى ضرورة

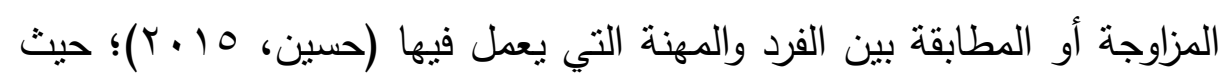
Choosing a بدأ العمل بخدمات الإرشاد المهني من خلال كتابه "اختيار مهنة Vocation اتباعها عند اختبار مهنة من المهن، وهي: دراسة استعدادات الفرد وإمكاناته وميوله، ودراسة المهن المختلفة وما تحتاجه من متطلبات واستعدادات، ووضع الفرد المناسب في المهنة المناسبة، أو ما يسمى بالموائمة بين الإمكانات الفردية

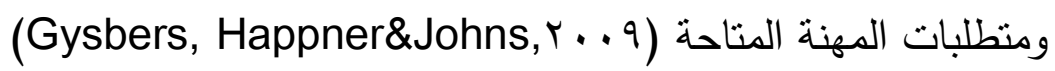

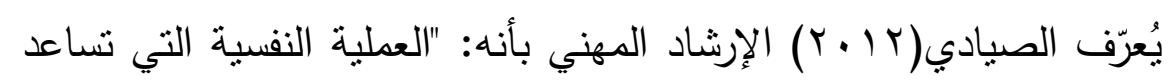

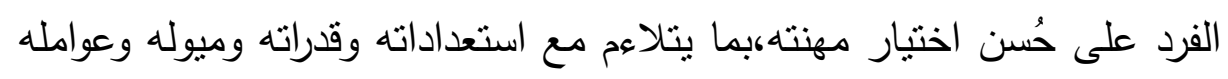
الاجتماعية ،وما ينسجم مع جنسه؛ فالإرشاد يتضمن مساعدة الفرد في اختيار مهنته، وفي تقرير مصيره المهني، وليس لأحد غيره أن يقرر نيابة عنه، أو أن يفرض عليه، وبذللك يتحمل مسؤولية نفسه". 
حيث يهدف الإرشاد المهني إلى تحقيق مجموعة من الأهداف، والتي تتمنل

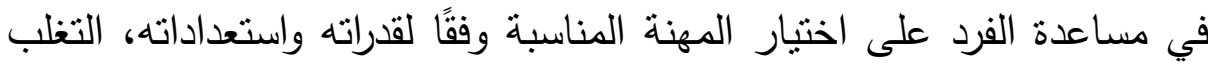
على المشكلات المهنية التي تعترض طريق نجاح الفرد في عمله، ومساعدة

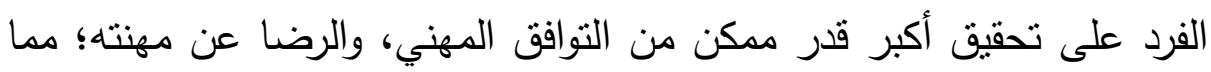

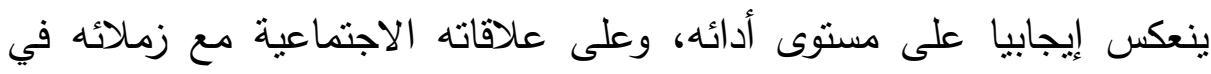

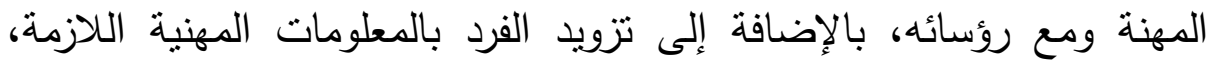

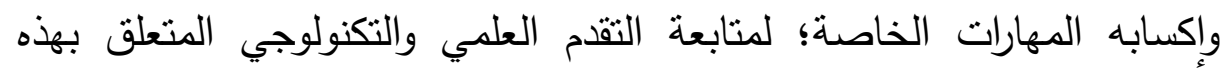
المهنة، والتعرف على المهن المختلفة وما تتطلبه من مهارات وقدرات، واستعدادات؛ حتى يتمكن الفرد من اختيار المهنة التي تلائمه( حسين ، 10 ـ ب).

كما يؤدي الإرشاد الهني الفعال إلى القرار الدهني السليم الذي يعكس

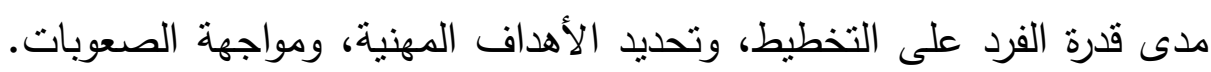

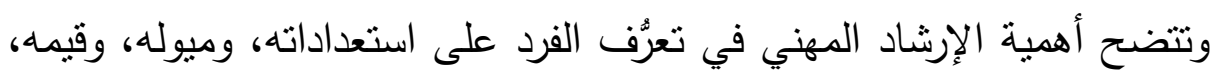

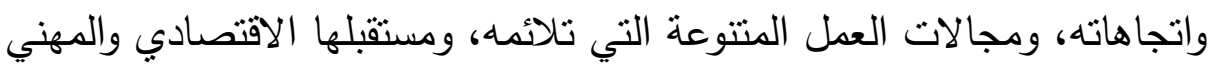

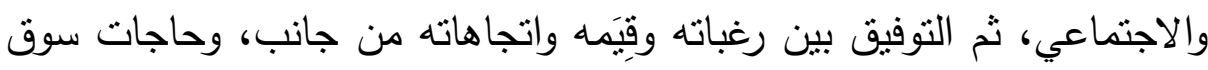

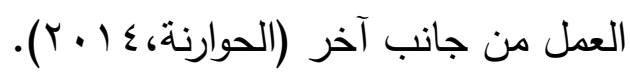

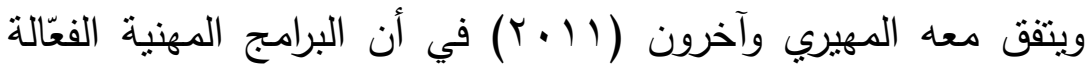

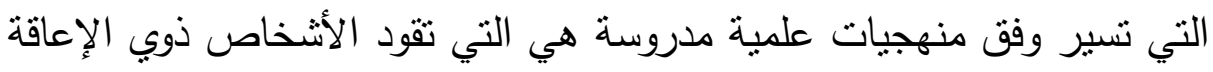

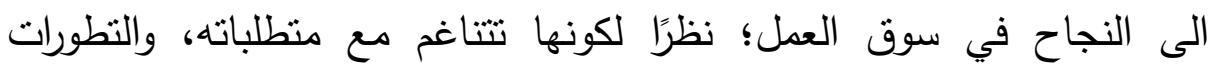

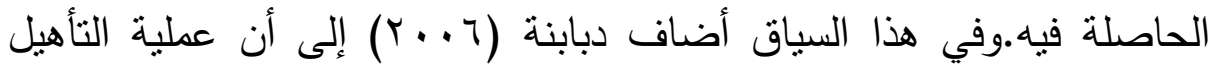

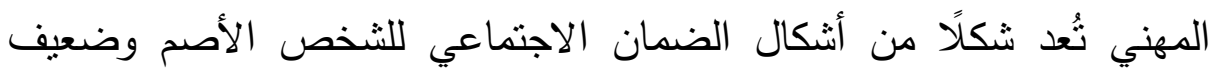

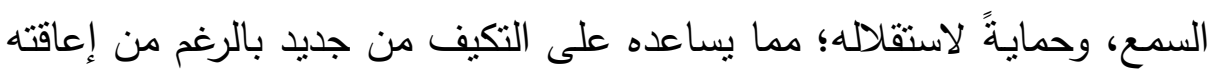

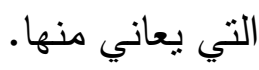


ونظرا لغياب الإرشاد المهني نجد أن هناك الكثير من الأفراد يعملون في مهن لا تتناسب مع ما لديهم من قدرات واستعدادات ومؤهلات، وذللك يعتبر كارثة بالفعل؛ حيث يقضي الفرد حياته في مهنة لا تتاسبه ولا يرضى عنها، وهذا لأنات ينعكس على علاقاته بالآخرين ومع زملائه في المهنة،وعلى توافقه الثخصي و الاجتماعي(حسين، 10 (ب).

فإن كان هذا ينطبق على الأثخاص من غير ذوي الإعاقة فماذا عن الأشخاص ذوي الإعاقة، الذين بعانون من ندرة برامج الإرشاد المهني الخاصة بهم.

فقد حدد الزارع (10 ب) أهداف الإرشاد المهني للأثخاص ذوبي الإعاقة، في: تزويد الأشخاص ذوي الإعاقة بمعلومات كافية عن فرص الندريب، وفرص العمل المتاحة والمناسبة لهم في سوق العمل، وكذلك تقديم المشورة حول المستقبل المهني الذب سيتيح لهم كل الفرص المككنة للنمو المهني، والرضا في العمل، عن طريق مساعته على تطور العمل بمرونة كافية وخبرات تجعلهم قادرين على مواجهة التطورات المنسارعة في حياتهم المهنية، بالإضافة إلى الى

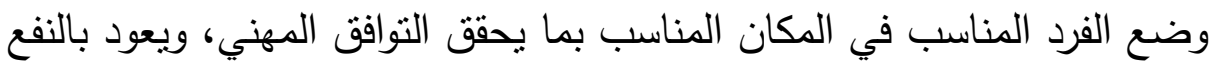
والفائدة على الفرد ذي الإعاقة وعلى المجتمع. فمن الصعوبات والمعوقات التي تكتتف عملية الإرشاد المهني للأثنخاص ذوي الإعاقة: عدم الفهم الواضح لطبيعة ومجال الإرشاد الدهني،

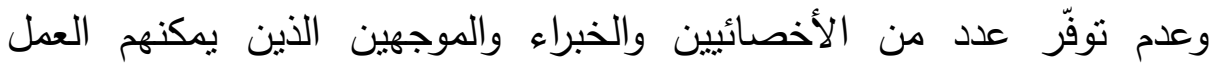

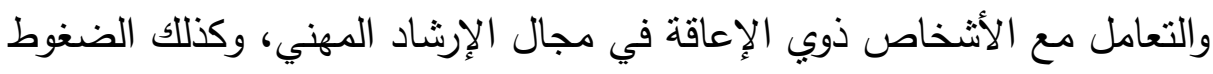
والثقاليد السائدة في المجتمع نحو مِهن معينة،والتي تعيق عملية الإرشاد المهني الإني

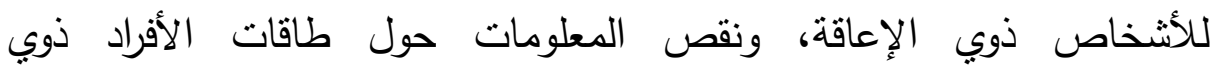
الإعاقة،واستعداداتهم، وإمكانياتهم، ونقص المعلومات المهنية التي يمكن الاعتماد

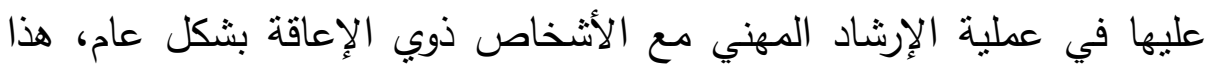


بالإضافة إلى عدم توافر العدد الكافي من مراكز الإرشاد المهني التي تخدم

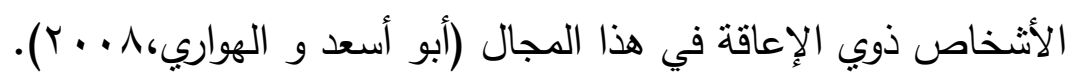

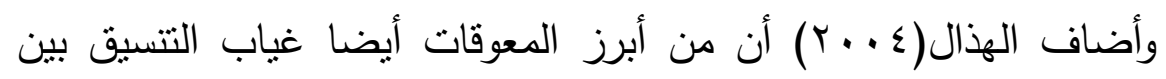

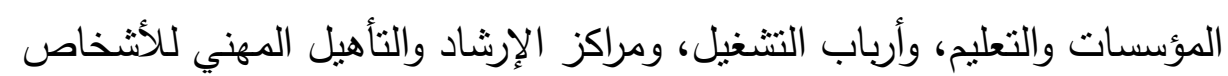

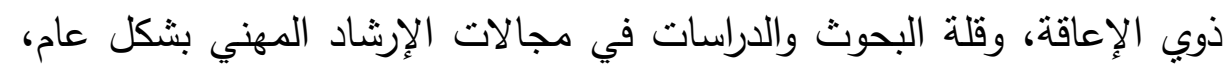
وللأشخاص ذوبي الإعاقة بشكل خاص.

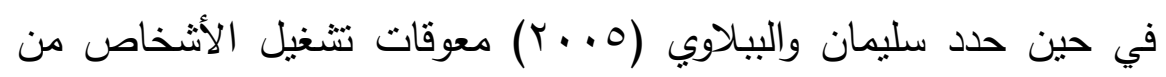
ذوي الإعاقة بشكل عام، والأشخاص من ذوبي الإعاقة السمعية في النقاط النالية:

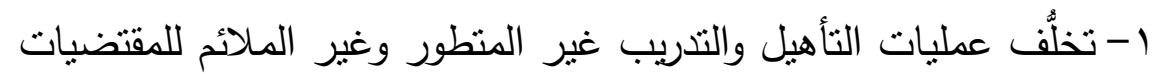
الحديثة،مع حدوث التقام التكنلوجي في الأدوات والمعدات. Y- انحصار عمليات إعادة التأهيل والتدريب على الفرص المهنية المتاحة

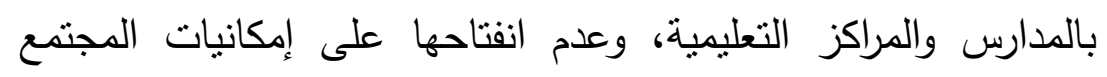
الحقبقية. r- عدم قبول الأثخاص ذوي الإعاقة السمعية كأعضاء لهم نفس الحقوق والنطلُعات من جانب العاديين بالثكل الكافي.

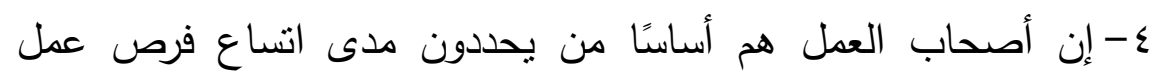

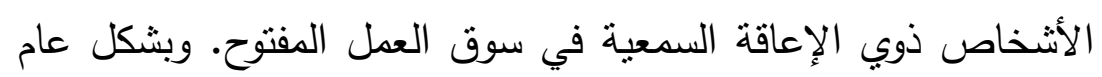

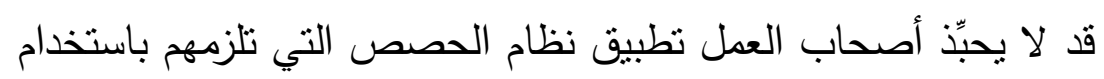

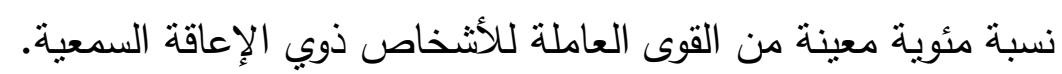
ه- إن أكثر الأفراد ذوي الإعاقة يعيشون في مناطق ريفية بعيدة عن الددينة

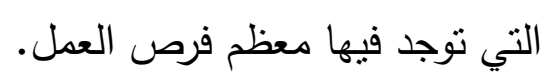
ج-ما زال الثخص ذو الإعاقة السمعية يتقبل دورًا سلبيًا في عملية إعادة

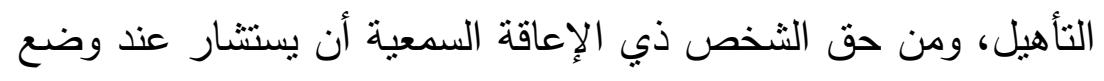
سياسة التأهيل المهني، واتخاذ القرارات التي تثماشى مع مستقبله. 
V- موقف بعض الأسر تجاه تتغيل الأفراد ذوب الإعاقة السمعية، خاصة

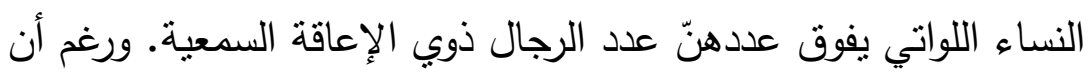

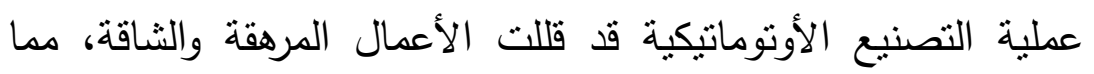
مكَّن من إيجاد فرص نتشيل للنساء ذوات الإعاقة السمعية والحصول

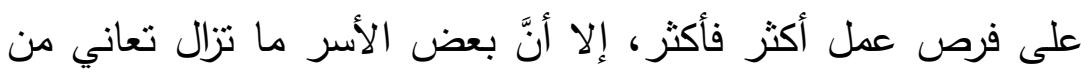
وصمة العار للإعاقة، والخوف الثديد من المشكلات التي نواجه نتشغيل الأشخاص ذوي الإعاقة السمعية بسبب العجز عن السمع.

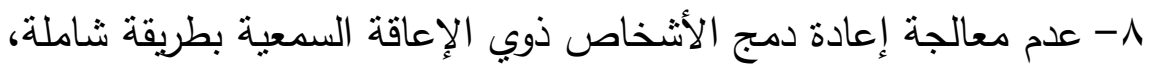
من خلال نظام كامل من التدابير العلاجية، والنفسية، والاجتماعية، والمهنية في الوقت المناسب.

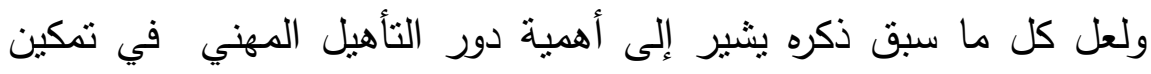
الثخص من التغلب على الآثار الناجمة عن العجز ، واكتساب أو استعادة دوره

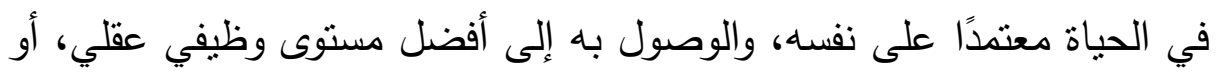
جسماني، أو اجتماعي.

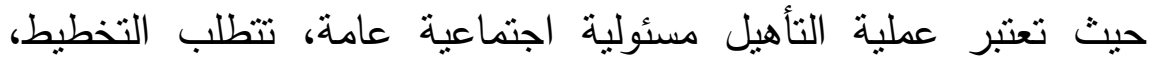

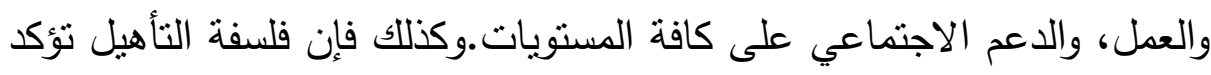
على الانتقال بالثخص ذي الإعاقة من قبول فكرة الاعتماد على الآخرين إلى الى الإلى ضرورة الاعتماد على الذات، وذلك عن طريق الاستقال الذاتي، والكفاية الإنية الثخصية والاجتماعية والمهنية، واستعادة الثخص ذي الإعاقة لأقصى درجة من درجات القدرة الجسمية أو العقلية أو الحسية الكتقية لديه، بالإضافة إلى الإنى

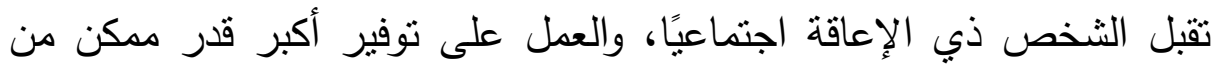

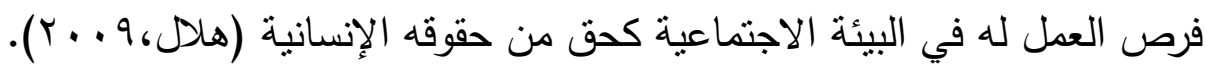

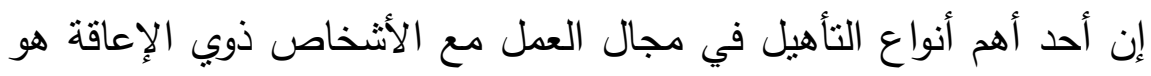

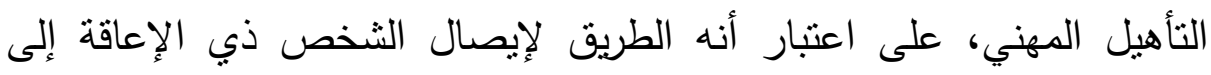


المجتمع الخارجي، من خلال إتاحة الفرصة له في العمل والكسب في ضوء قدراته المتبقية وإلى أقصى حد مدكن، واستتمار ما يتوافر لايه من استعدادات

$$
\text { وقدرات(المعايطه والقمش، V. . . Y). }
$$

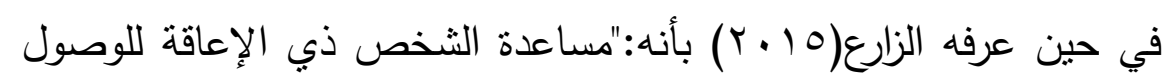
إلى قرارات حاسمة تتعلق بشؤونه الخاصة، ومساعدته في الكثف عن قدراته داته وصفاته الفردية التي يمكن الاستعانة بها بقر الإمكان في التعلم والتدريب على بلى فئله أداء عمل أو مهنة ما تعود عليه وعلى المجتمع بالفائدة".

ولابد من مراعاة نظريات الإرشاد والنمو والإختيار المهني قبل البدء في برامج الإرشاد المهني ومنها:

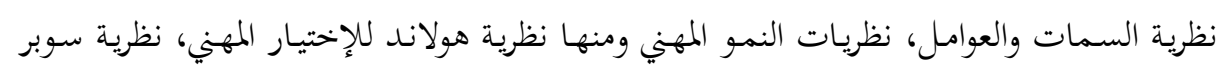

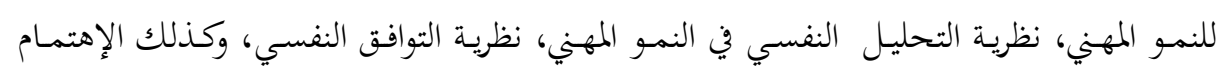

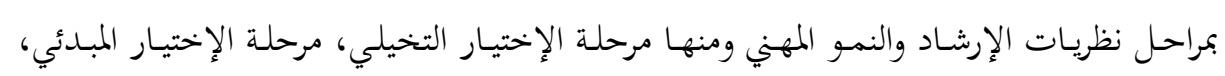

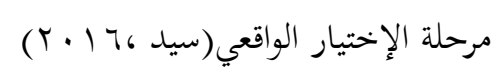

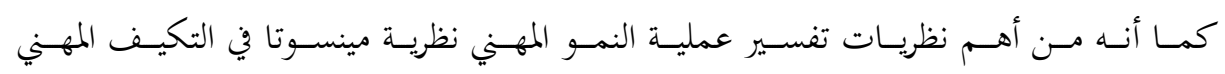
التي اهتمت بتطوير نظام لتقديم (Minnesota Theory of Work Adjustment)

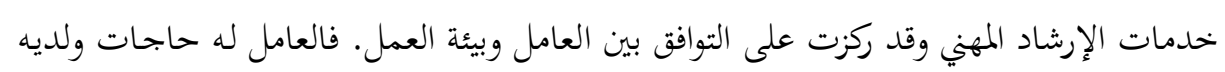

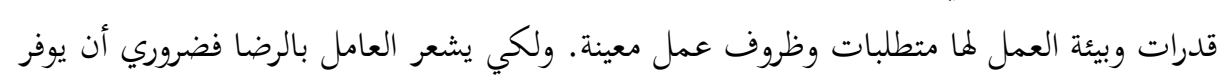

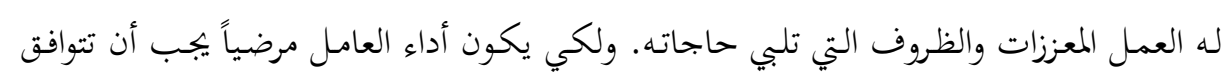

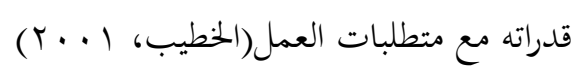

وترى الباحثة أن نظريات الإرشاد والتأهيل المهني تركز على احترام الإنسان واستثمار طاقاته باعتباره

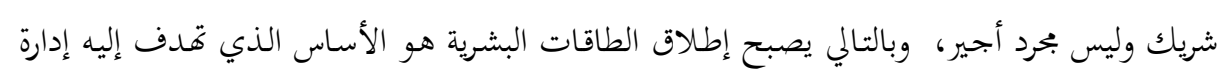

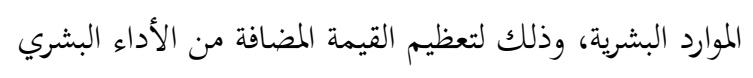

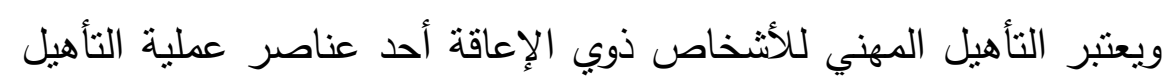
المنسقة والثاملة، التي تهدف إلى تمكين الثخص ذي الإعاقة من الاندماج 
الاجتماعي والاقتصادي في المجتمع، وذلك من خلال تدريبه على مهنة مناسبه

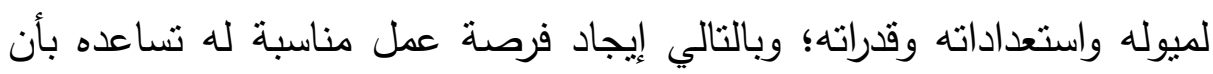

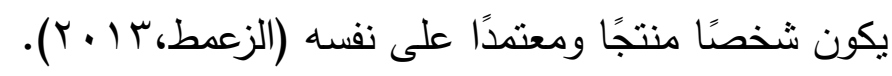

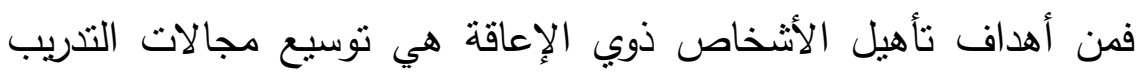

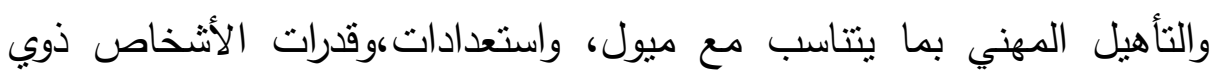
الإعاقة. نوفير فرص العمل والتتغيل في مختلف قطاعات النشاط الاقتصادي،

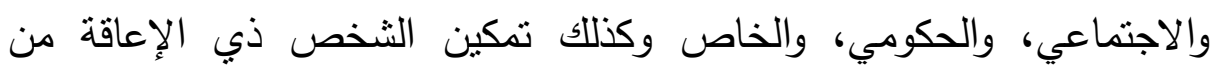

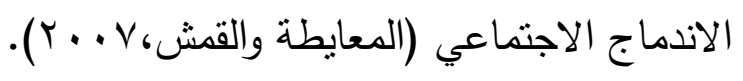

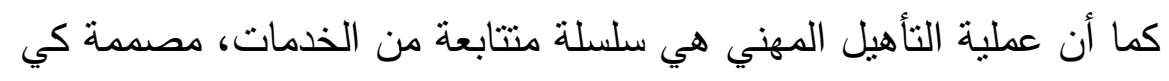
تنقل الفرد ذو الإعاقة نحو هدف النتخيل في مهنة ذات فائدة وكسب. ويشكّل

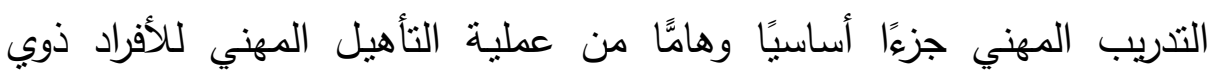

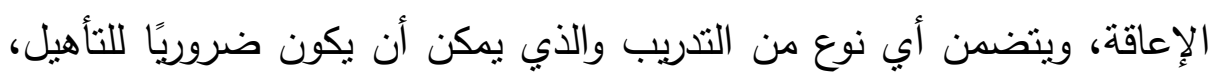

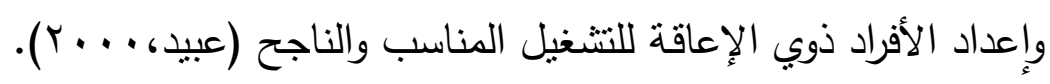

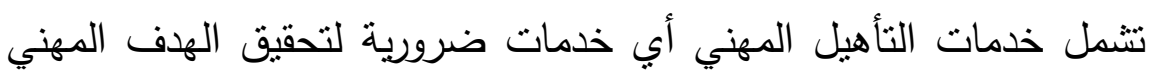
اللثخص ذي الإعاقة، وتتضمن هذه الخدمات ما يلي: 1- التقييم: وهو الحصول على صورة واضحة لما تبقى لدى الثخص ذي لني

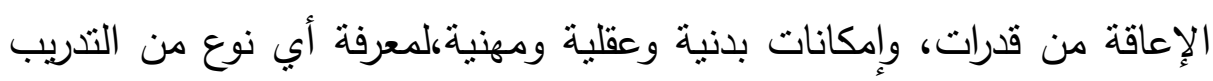

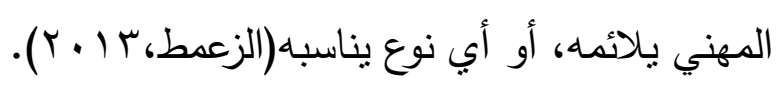

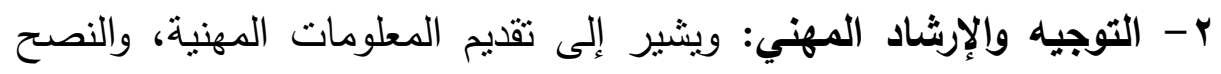

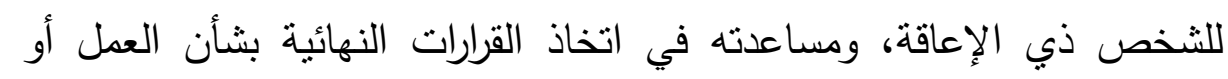

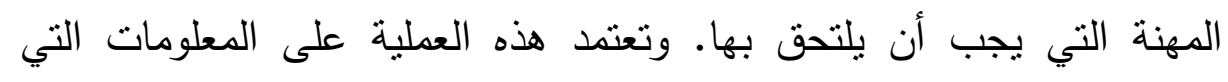

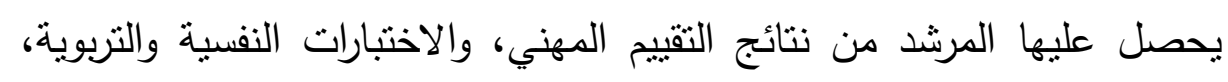

$$
\text { والفحوص الطبية (عبيد، ..... ب). }
$$


ץ- الإعداد للعمل والتتريب المهني: وهو تدريب الثخص ذي الإعاقة على

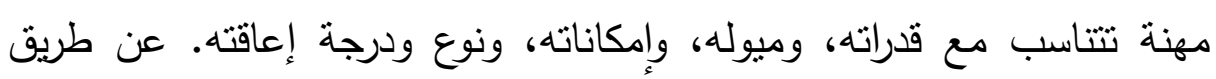

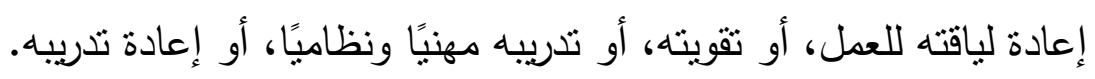

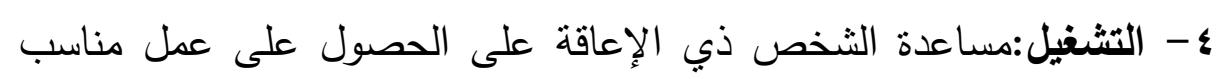
لقدراته، وإمكاناته في ضوء التدريب الذي حصل عليه.

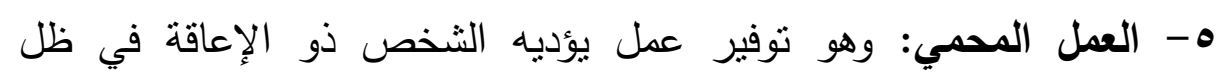
ترتيات خاصة.

צ- المتابعة:متابعة الثخص ذي الإعاقة إلى أن تتحقق إعادة التشغيل

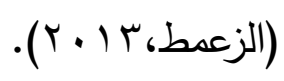

\section{الاراسات السابقة}

هناك ندرة في الدراسات التي تتاولت الإرشاد والتأهيل المهني لدى الدابه

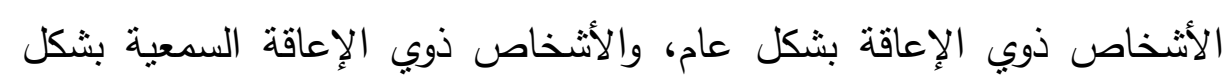

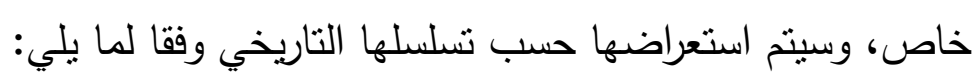

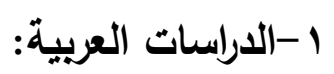

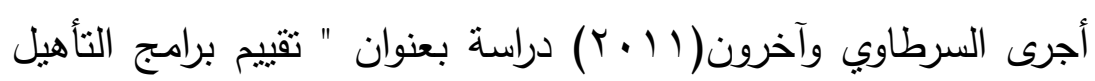

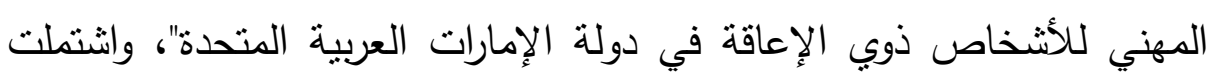

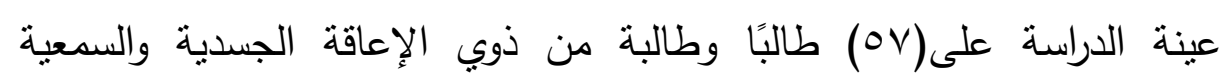

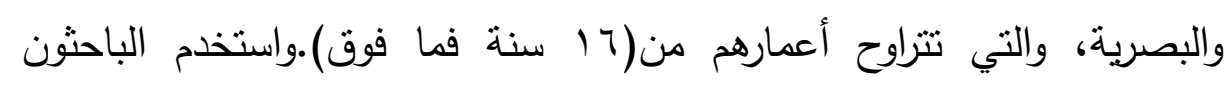

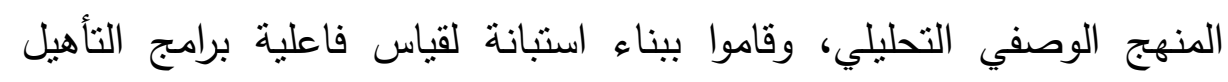

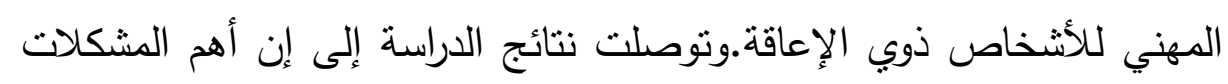

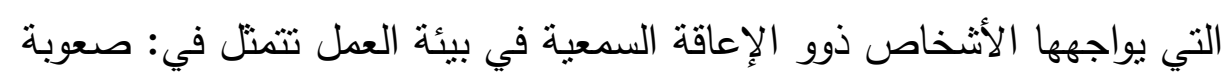

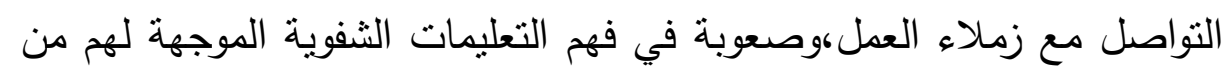


المشرف المباشر ، ومشكلات في قراءة التعليمات والبيانات المكتوبة، وعدم توفر مؤهلات علمية عليا لدى الكثير منهم، بالإضافة إلى عدم إتقان بعض المهارات؛ منل اللغة الإنجليزية.

في حين أجرى مغربي (ع (ب) دراسة تهدف إلى التعرف على أنواع الصعوبات التي تواجه الطلاب ذوي الإعاقة السمعية أثناء التأهيل المهني بمركز التأهيل والتدريب بالكلية التقنية بالقصيم، وذلك على عينة مكونة من (VV)

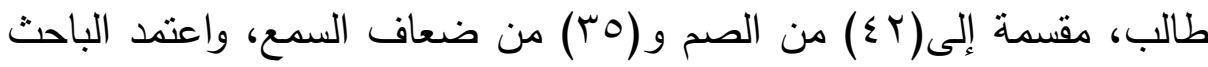
المنهج الوصفي، وطبق استبانة الصعوبات التي نواجه المعاقين سمعيًا أثناء

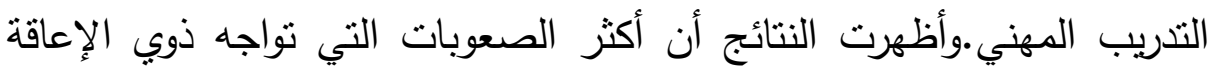

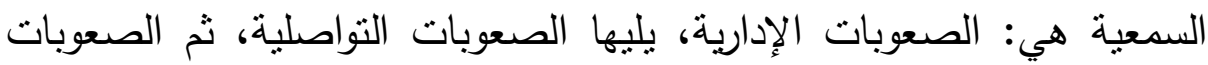

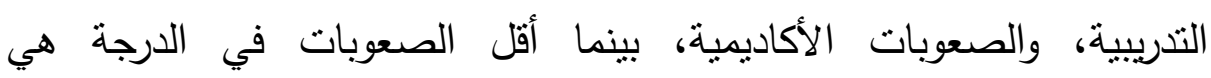
الصعوبات السلوكية الانفعالية.

كما قام الثناويش(ع ( ب ب) بدراسة تهدف إلى بناء برنامج للتأهيل المهني للأثخاص ذوي الإعاقة السمعية وفق الممارسات المهنية الحديثة، وتقييمه من قبل الأشخاص ذوي الإعاقة السمعية والمشرفين عليهم الذين بعملون في مراكز

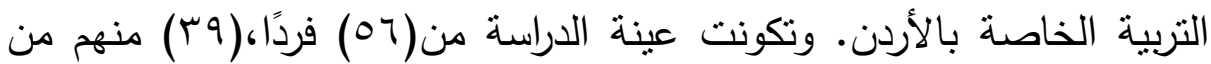
ذوي الإعاقة السمعية،و(IV) مشرفًا في مراكز التربية الخاصة. وقام الباحث بتطوير مقياس تقييم برامج التأهيل المهني لذوي الإعاقة السمعية، كما قام بيناء برنامج للتأهيل المهني لذوبي الإعاقة السمعية. وكثفت نتائج الدراسة أن مستوى التئي

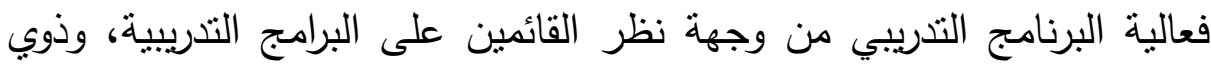
الإعاقة السمعية كان مرتفعًا،مع عدم وجود فروق ذات دلالة إحصائية في فاعلية

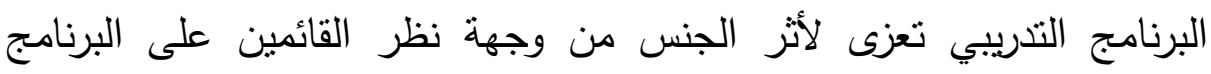


التدريبي، ووجود فروق ذات دلالة إحصائية في فاعلية البرنامج التدريبي تعزى لأثر الجنس لصالح الذكور من وجهة نظر ذوي الإعاقة السمعية.

أما دراسة المعيقل (10 ب ب) فهدفت إلى التعرف على واقع ومعوقات تطبيق برامج التوجيه والإرشاد المهني في معاهد وبرامج التربية الفكرية الحكومية والأهلية والجمعيات الخيرية في مدينة الرياض من وجهة نظر العاملين بها، وعلاقتها بمتغيرات(الجنس،وطبيعة العمل، ونوعية المدرسة)، وقد اتبعت الدراسة

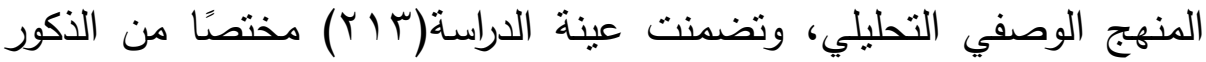
والإناث، من المعلمين، والمعلمات، ومعلمي التدريبات السلوكية، والمرشدين الطلابيين العاملين في برامج التربية الفكرية في الرياض. وقد أظهرت نتائج الدراسة ما يلي:انخفاض متوسط مستوى تطبيق برامج التوجيه والإرشاد المهني في معاهد وبرامج التربية الفكرية الحكومية والأهلية والجمعيات الخيرية في مدينة الرياض،أما فيما يخص المعوقات فقد حصل نقص الإمكانات المكانية على أكثر نسبة استجابة من بين المعوقات.

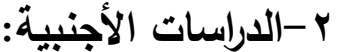

دراسة ستوك، وديفيس، وسيكور، وويم (r. Stock et al) والتي هدفت إلى استخدام التقنية في التوجيه والإرشاد المهني؛ حيث قام الباحثُن بتقييم فاعلية استخدام برنامج حاسوبي باستخدام الوسائط المتعددة والفيديو، لتمكين الأثخاص ذوي الإعاقة الفكرية من التعبير عن اهتماماتهم الوظيفية بثكل مستقل بالدقارنة مع أدوات التقييم الوظيفي المستخدمة حاليًا من قبل

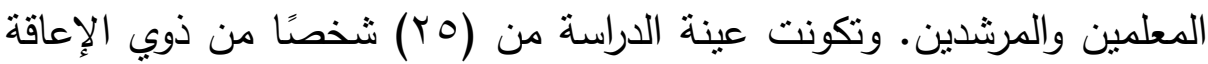

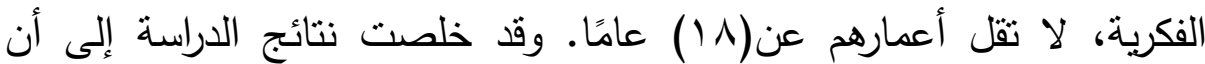
استخدام تقنية الوسائط المتعددة القائمة على توفير المعلومات عن العمل، تمكّن 
الأثخاص ذوي الإعاقة الفكرية من التعبير عن الأعمال التي يفضلونها

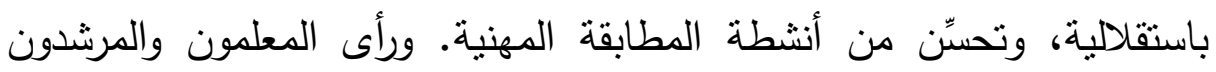

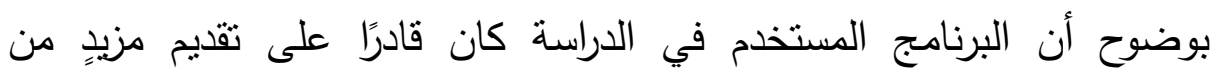

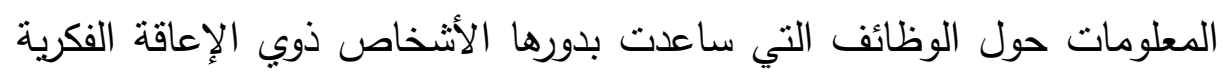

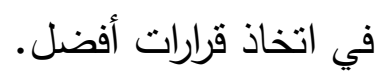

Cocks, Thoresen\& Lewis ودراسة كوكس وثوريزن ولويس

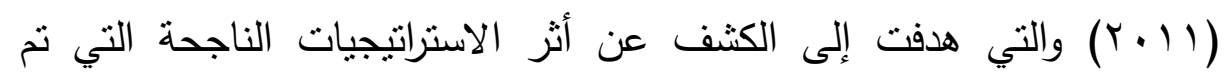

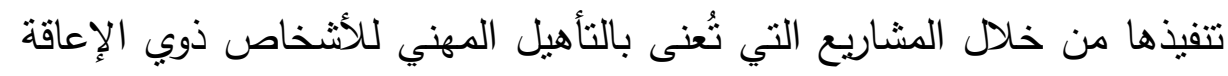

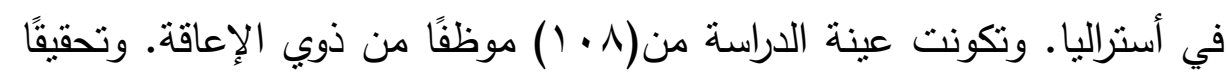

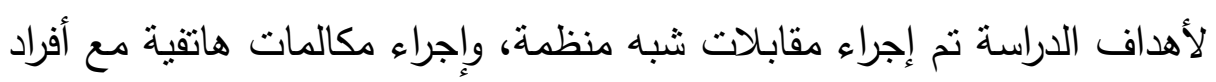

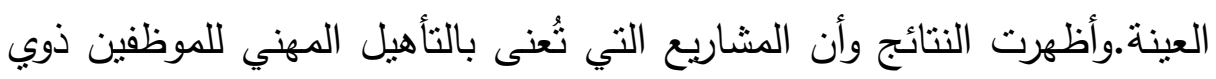

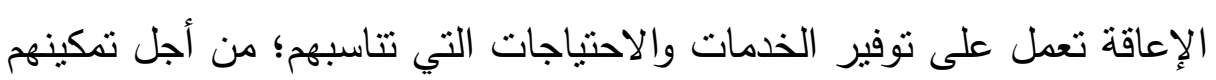

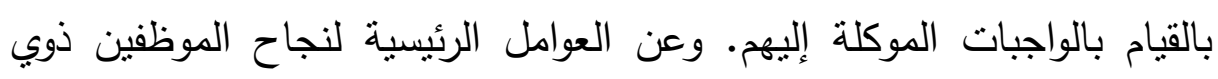

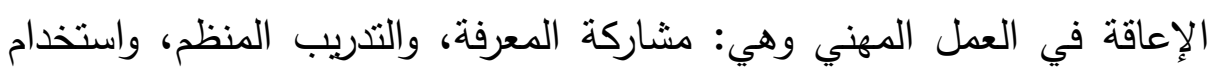

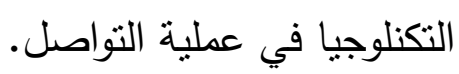

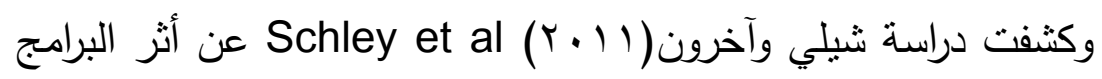

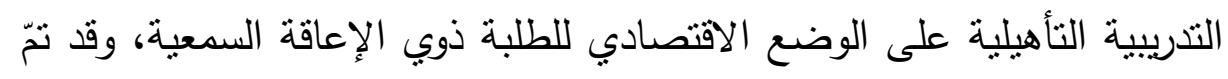

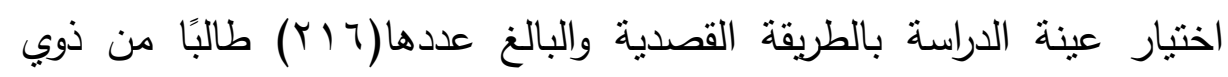

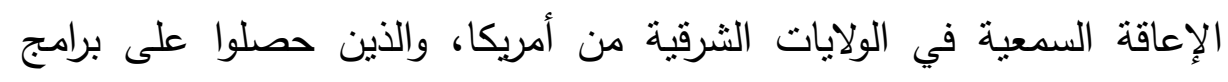

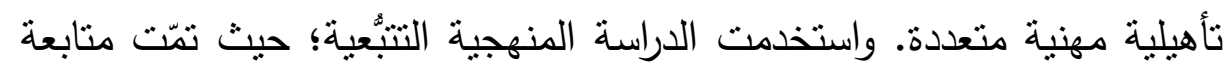

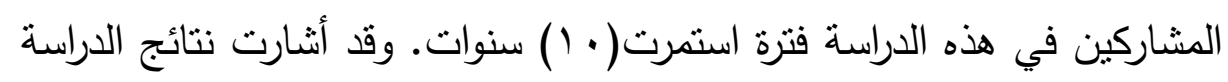

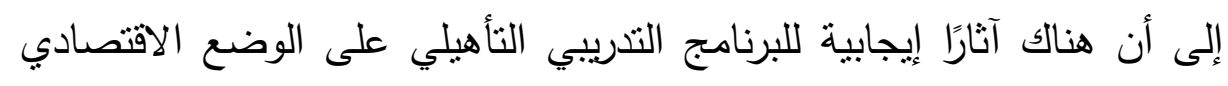


للطلبة ذوي الإعاقة السمعية،وأن المشاركة في برنامج تدريبي تأهيلي يعزز من إمكانية الحصول على فرصة عمل لدى الطلبة ذوب الإعاقة السمعية.

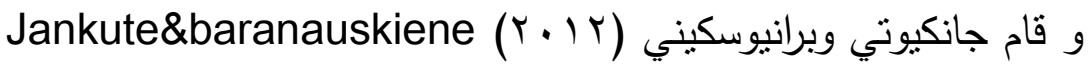

بدراسة هدفت إلى الكثف عن أثر مراكز الإرشاد المهني في الددارس على

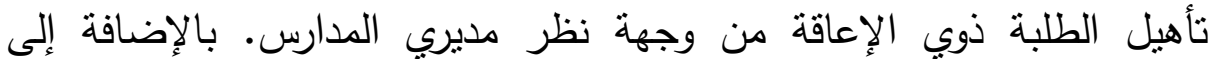
الكثف عن أهم الاستشارات التي يمكن أن يقدمها المركز من أجل تأهيل هوئلاء

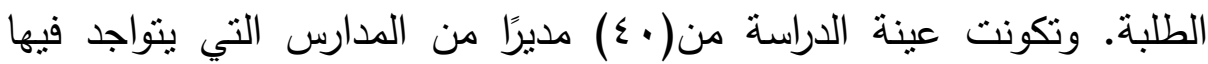
مركز إرشاد مهني في مدينة لينوانيا في تركيا، منهم(9 (1) مديرة و (Y) مديرًا. وتحقيقًا لأهداف الدراسة نم بناء مقياس، وإجراء مقابلة شبه منظمة مع مدراء فئاء الددارس؛ للكثف عن أثر مراكز الإرشاد المهني في المدارس على ثأهيل الطلبة

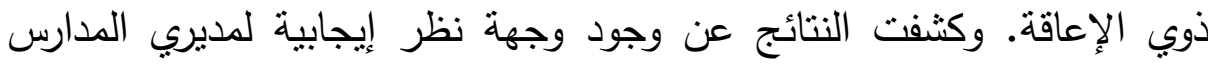
نحو إيجاد مراكز إرشاد مهني لتأهيل الطلبة ذوي الإعاقة؛ لما لها من فائدة كبيرة

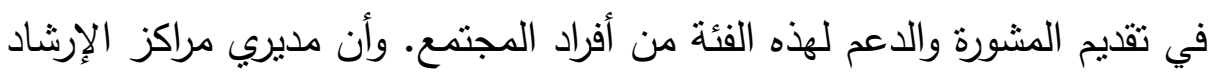

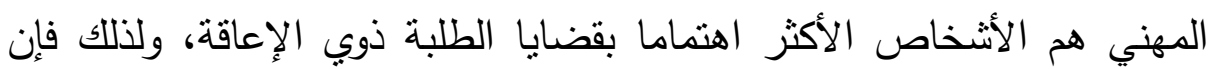

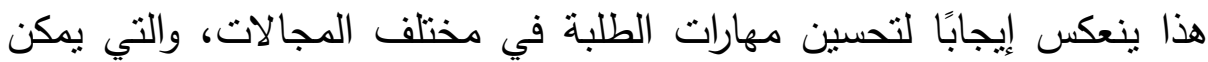
تطبيقها في سوق العمل وذللك من خلال ما تقدمه هذه المراكز من مشورات للطلبة ذوي الإعاقة.

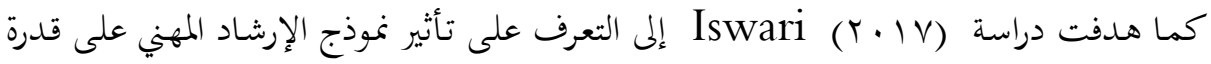

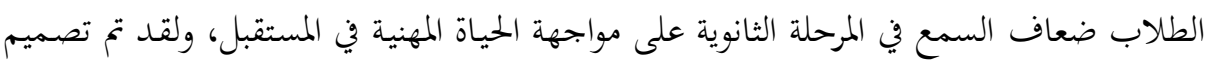

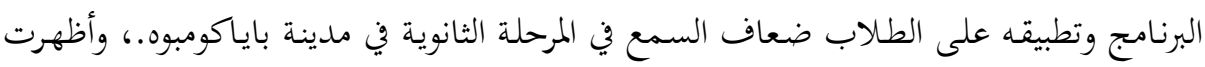

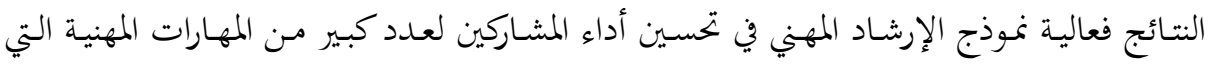

$$
\text { تناسب قدراقم وتمكنهم من العمل المستقل في المستقبل. }
$$

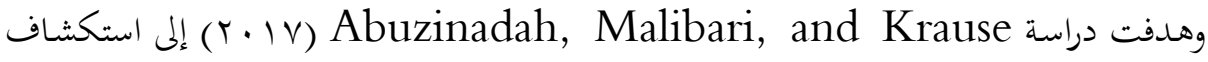

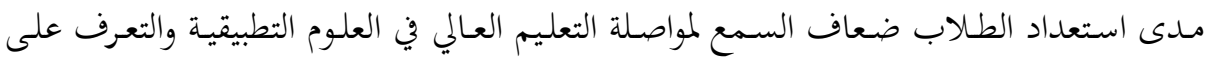




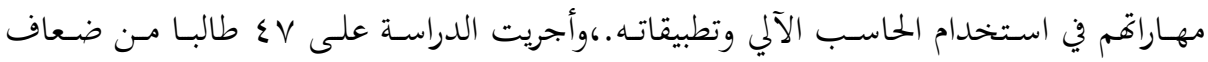

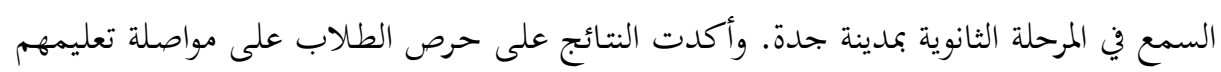
العالي وتطوير مهارات استخدام الحاسب الآلي لديهم حيث أخان تساهم في تأهيلهم لسوق العمل.

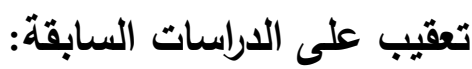

يتضح أن نتائج بعض الدراسات التي بحثت في الصعوبات والعقبات

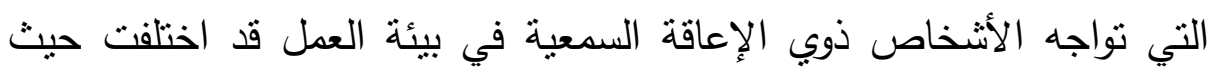

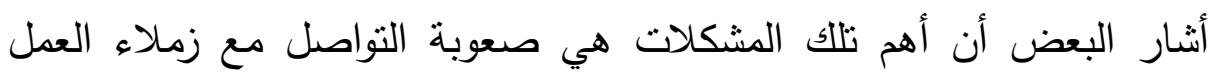

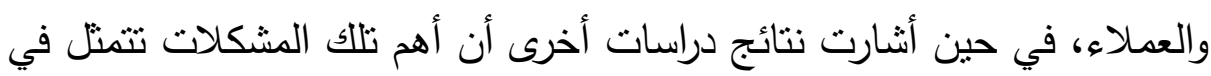
الصعوبات الإدارية، ودراسات أخرى أثشارت نتائجها إلى أن الصعوبات الصنات الكانية

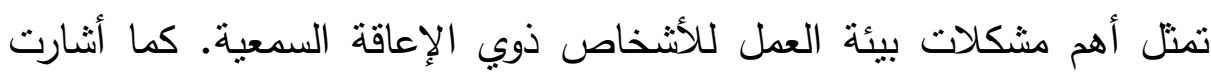
نتائج الدراسات التي بحثت في فعالية برامج التنريب الدهني إلى فعالية تلاك

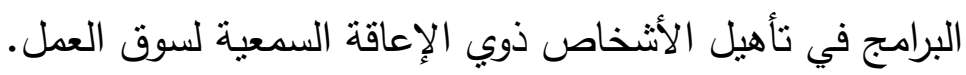

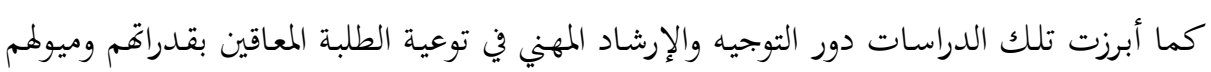

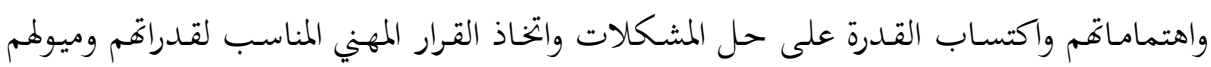

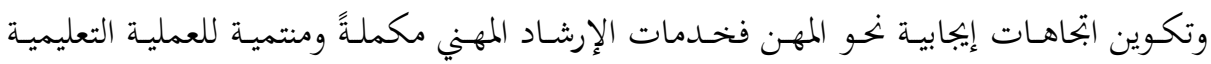

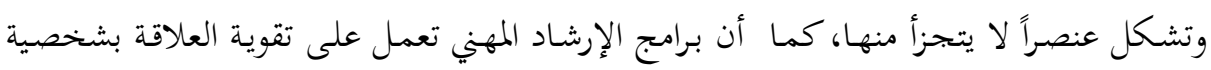

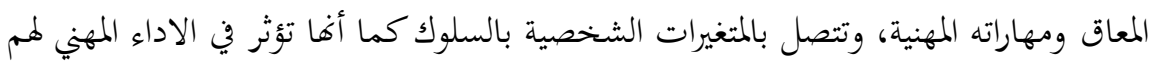

\section{منهج الدراسة وإجراء|تها

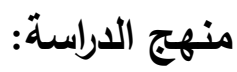

تتبع الدراسة المنهج الوصفي حيث اهتمت الباحثان بوصف دور

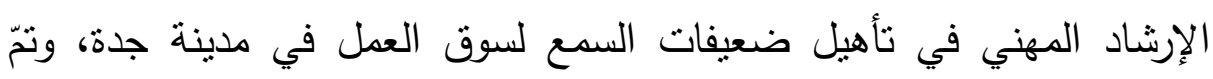


استخدام المنهج المسحي لقياس مستوى رضا ضعيفات السمع عن دور الإرشاد المهني في تأهيلهن لسوق العمل في مدينة جدة. عينة الدراسة:

تكونت عينة الدراسة من الطالبات ضعيفات السمع بالمرحلة الجامعية

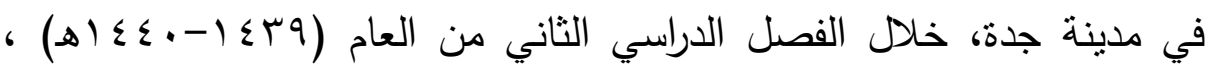
ويقدر عددهن بـ (Y^) طالبة في جامعات جدة الحكومية(جامعة الملك عبد العزيز - جامعة جدة). وقد تمّ اختيار عينة الدراسة قصديًا؛ ممثلة لمجتمع الدراسة الذي يقدر عدد طالباته بـ (Y^) طالبة، منهن (^) طالبات من جامعة الملك عبد العزيز، و(·) (r) طالبة من جامعة جدة. ويوضح الجدول رقم (1) توصيفًا لأفراد العينة.

جدول (1)

توزيع أفراد العينة تبعا لمتغير التخصص جار

$(r \wedge=\dot{0})$

\begin{tabular}{|c|c|c|c|}
\hline النسبة & العدد & الفئات & المتغير \\
\hline$\% \vee \wedge .7$ & rr & رسم وفنون & \multirow{3}{*}{ التخصص } \\
\hline \%rl.z & 1 & علوم إدارية & \\
\hline$\% 1 \ldots$ & r^ & المجموع & \\
\hline
\end{tabular}

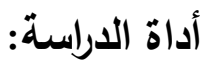

لتحقيق أهداف الدراسة قامت الباحثنان بإعداد مقياس دور الإرشاد

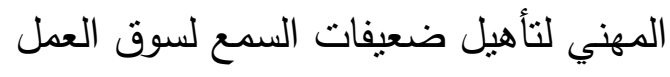


قامت الباحثتان بينائه بعد الاطلاع على الأدبيات المتعلقة بموضوع

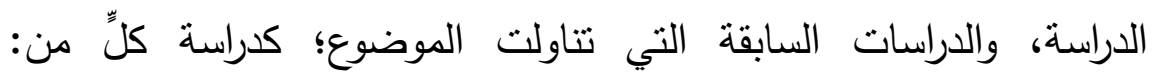

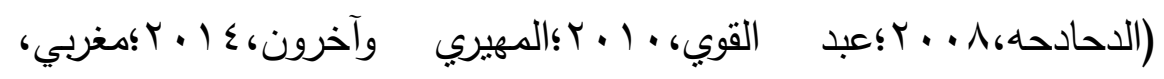

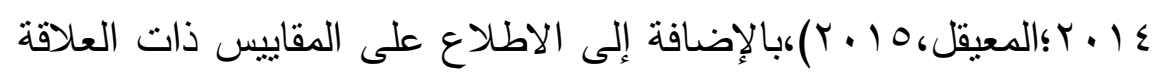

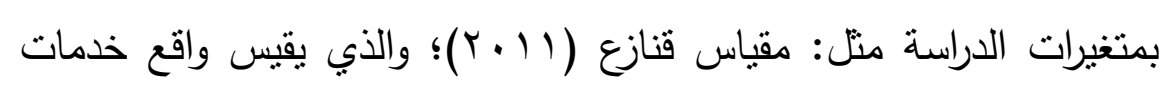

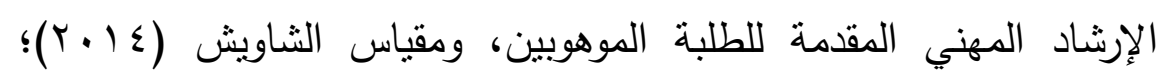
والذي يقيس فاعلية برنامج تأهيل مهني للمعاقين سمعيًا.

ثم قامت الباحثتان بإعداد مقياس تضمّن المحاور والأبعاد التالية:

أ- المحور الأول:واقع خدمات الإرشاد المهني المقدمة للطالبات ضعيفات

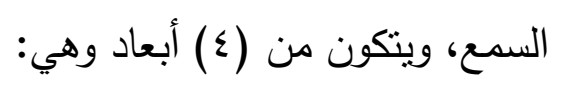

1- البعد الأول: وتقيس فقراته طرق تزويد الطالبات ضعيفات السمع بخدمات

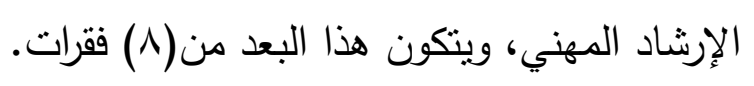

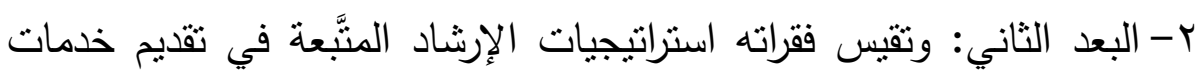

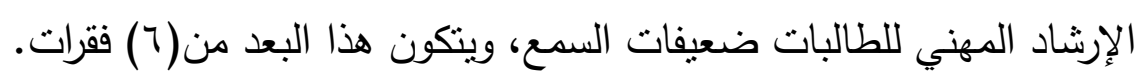

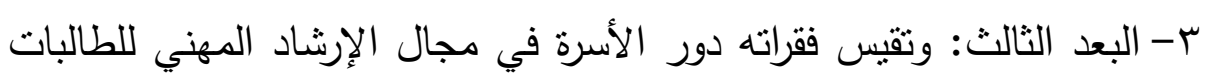

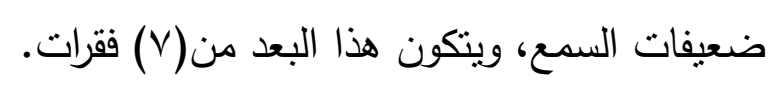

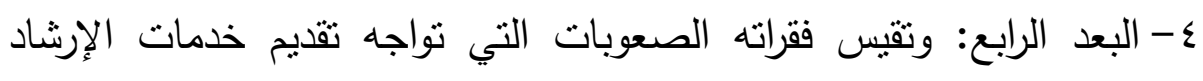

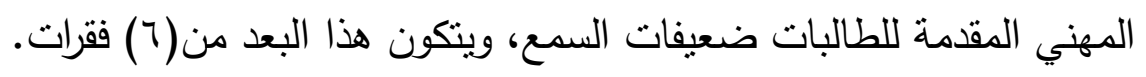

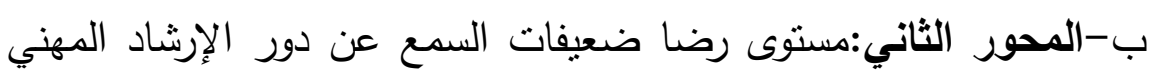

في تأهيلهن لسوق العمل، ويتمنل في بُدِدٍ واحد مكون من (؟) فقرات.

وللتحقق من الخصائص السيكومترية لدقياس دور الإرشاد المهني

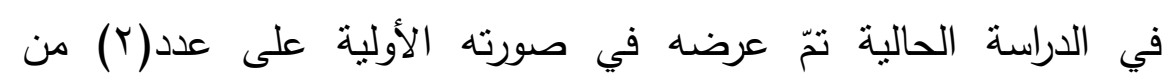


المحكمين من ذوي الاختصاص في مجال التربية الخاصة، كما نم عرضها

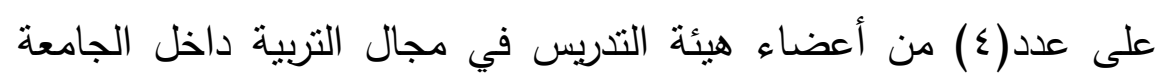
وخارجها للتحقق من الصدق الظاهري، وفي ضوء نهاء نتائج التحكيم تمّت مراجعة المقياس في صورته الأولية، وإجراء التعديلات لبعض الفقرات لتلائم الغرض من الدراسة.

وللاطمئنان على صدق وثبات الأداة، والتأكد من خصائصها

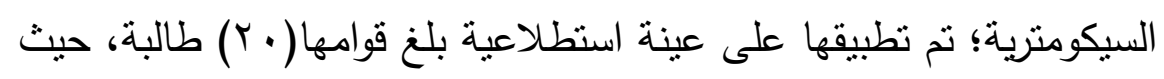
تم حساب صدق البناء عن طريق حساب قيم معاملات الارتباط بين كل

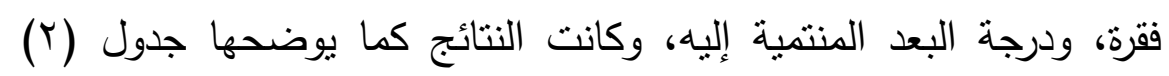
كالأتي:

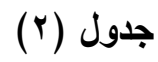

قيم معاملات الارتباط بين درجات فقرات المقياس، ودرجة البعد المنتمية إليه

\begin{tabular}{|c|c|c|c|c|c|c|c|c|c|}
\hline \multicolumn{10}{|c|}{ (العينة الاستطلاعية: ن=• ب) } \\
\hline قيم معامل الارتباط & p & معامل & p & قيم معامل & b & معامل & b & البعد البع & المحور \\
\hline$* * . . V$ & $\varepsilon$ & $* * . . \wedge \varepsilon$ & $r$ & $* * . . \wedge r$ & $r$ & $* * \ldots V Y$ & 1 & البعد & \multirow{8}{*}{$\begin{array}{l}\overline{3} \\
\overline{7} \\
\overline{3}\end{array}$} \\
\hline$* * . . \wedge r$ & $\wedge$ & $* * .91$ & V & **..人 & 7 & $* * .94$ & ○ & 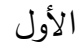 & \\
\hline$* * . .9 \leq$ & ir & $* * .94$ & 11 & $* * . .9 \varepsilon$ & 1. & $* * .9 \leq$ & 9 & 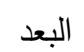 & \\
\hline & & & & $* * . .94$ & $1 \varepsilon$ & $* * . \wedge \wedge$ & r & 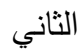 & \\
\hline$* * . . \wedge \wedge$ & 11 & $* * . . V r$ & iv & $* * . .77$ & 17 & $* * . .0$ & 10 & \multirow{2}{*}{ البعد } & \\
\hline & & $* * .9$. & Y) & $* * . .9 \varepsilon$ & $r$. & $* * . . \wedge 9$ & 19 & & \\
\hline$* * . .0 \mathrm{~V}$ & ro & $* * .7 \varepsilon$ & $r \varepsilon$ & $* * . \Delta r$ & r & $* * . . \wedge 1$ & rt & \multirow{2}{*}{ البعد } & \\
\hline & & & & $* * .79$ & rV & $* * . . \wedge$. & r & & \\
\hline$* * . .0 \leq$ & ו & $* * . \wedge$ & r. & $* * . . \vee q$ & rq & $* . . \leqslant \vee$ & $r \wedge$ & \multicolumn{2}{|c|}{ المحور الثاني } \\
\hline
\end{tabular}




\begin{tabular}{|c|c|c|c|c|c|c|c|c|c|}
\hline قالارتباط معامل & r & معامل & p & قيم معامل & e & معامل & p & البعد & المحور \\
\hline & & & & $* * . \Delta r$ & זr & $* *$ *. V & Tr & & \\
\hline
\end{tabular}

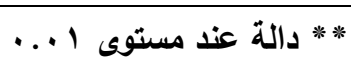

* دالة عند مستوى 0...

يتضح من الجدول رقم(Y) أن جميع قيم معاملات الارتباط دالة إحصائيًا عند المستوبين(0. . •)، و( ( . •)،وقد تراوحت قيم معاملات الارتباط الدالة ما بين(9 ـ . - 9 ـ • )؛مما يدل على صدق المقياس وصلاحية استخدامه لتحقيق أغراض الدراسة.

كما قامت الباحثنان بحساب صدق البناء عن طريق حساب قيم معامل الارتباط بين أبعاد المقياس والدرجة الكلية وجاءت النتيجة كما يوضحها جدول

جدول (r) (ب)

قيم معاملات الارتباط بين درجات أبعاد المحور الأول بالارجة الكلية للبعد

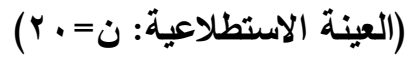

\begin{tabular}{|c|c|c|}
\hline قيم معامل الارتباط & 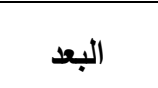 & المحور \\
\hline$* * .91$ & البعد الأول & \multirow{4}{*}{ المحور الأول } \\
\hline$* * . .9 \leq$ & البعد الثاني & \\
\hline$* * .$. & البعد الثالث & \\
\hline$* * .94$ & البعد الرابع & \\
\hline
\end{tabular}

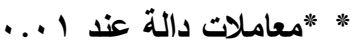

يتضح من الجدول(r) أن قيم معاملات الارتباط بين درجة كل بُعد،

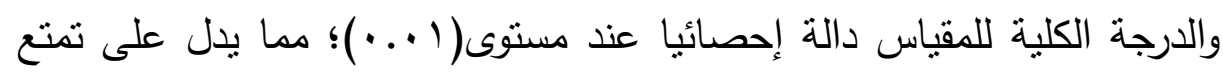
أداة الدراسة بدرجة مرتفعة من الصدق. 
كما نّّ التحقق من الثبات من خلال إيجاد قيمة معامل ألفا كرونباخ، ومعامل التجزئة النصفية، ومعامل معادلة سبيرمان- براون لفقرات المقياس. ويعرض جدول (ع) لذلك:

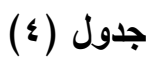

قيم معاملات ثبات أبعاد المقياس (كاس

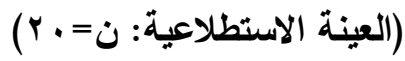

\begin{tabular}{|c|c|c|c|c|c|}
\hline سبير معامل & قالتيم معاملة & قريم معامل & البنود & أبعاد المقياس & المحاور \\
\hline. .91 & .9. & .94 & $\wedge$ & البعد الأول & \multirow{5}{*}{ الأول } \\
\hline .94 & .94 & .94 & 7 & البعد الثاني & \\
\hline. .14 & .1 .10 &..$\wedge \Lambda$ & v & البعد الثالث & \\
\hline$\cdot . \wedge \varepsilon$ &.$\wedge \varepsilon$ &.$\lambda r$ & 1 & البعد الرابع & \\
\hline. .19 & $\cdot . \wedge 1$ & .90 & rv & الدرجة الكلية للمحور الأول & \\
\hline.$\wedge 1$ & $\therefore .$. &..$V Y$ & 7 & المحور الثاني & \\
\hline
\end{tabular}

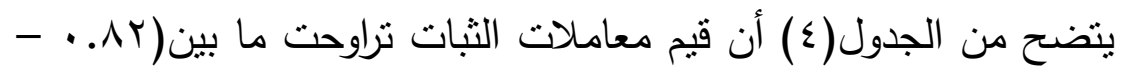

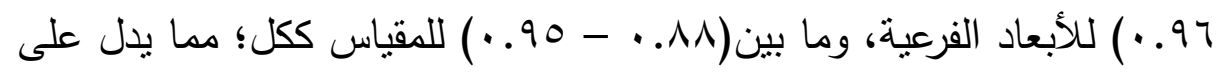
تمتع المقياس بمكوناته بدرجة جيدة من الثبات.

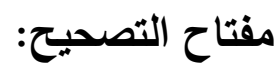

تم وضع خمس استجابات أمام كل فقرة، وفقًا لمقياس ليكرت الخماسي (موافق بشدة، موافق، محايد، غير موافق، غير موافق بثدة)، وكان مفتاح

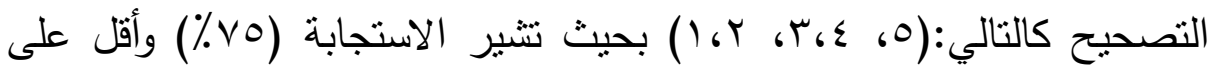




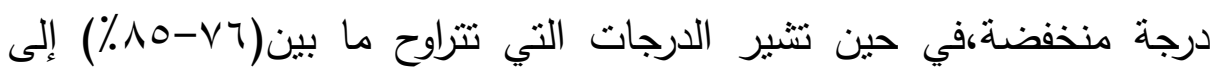

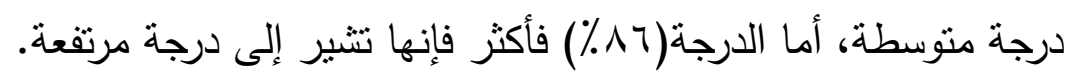

\section{نتائج الدراسة وتقسبرها}

للإجابة على السؤال الفرعي الأول والذي ينص على:"ما واقع الارشاد

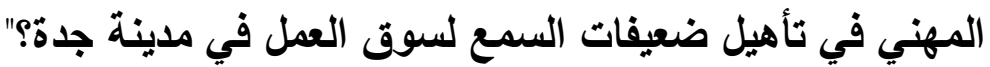

قامت الباحثة بحساب المتوسطات الحسابية والانحرافات المعيارية

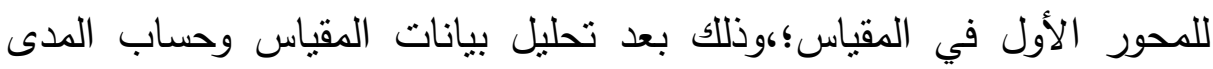

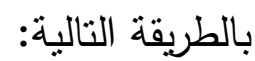

المدى =أكبر قيمة في المتوسط الحسابي- أقل قيمة في المتوسط

$$
\text { الحسابي:0=1-0 }
$$

$$
\text { كما تم تحديد طول الفئة :؟ 0.1.1. }
$$

وتم اتباع التقسيم التالي لتحليل بيانات المقياس:

1- الكتوسطات الحسابية الواقعة بين(0 - 1.Y.Y) تقع ضمن درجة تحقق

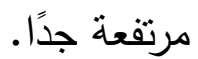

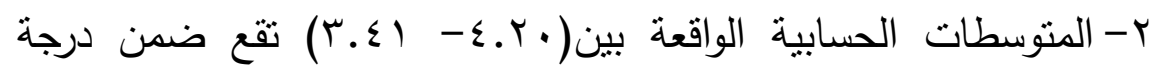

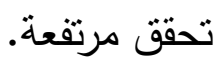

r- الكتوسطات الحسابية الواقعة بين(•؟.ب- (T.ب) تقع ضمن درجة

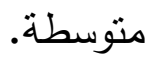




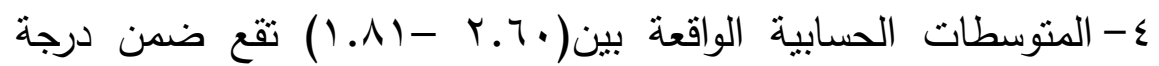

منخفضة.

ه- المتوسطات الحسابية الواقعة بين(• •1. - 1) تقع ضمن درجة منخفضة جدًا.

جدول (•)

المتوسطات الحسابية والانحرافات المعيارية للبعد الأول:

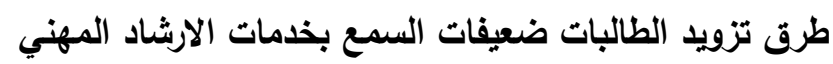

$(r \wedge=\dot{0})$

\begin{tabular}{|c|c|c|c|c|}
\hline الترتيب & التحقق & 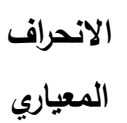 & المستوسط & الفقرات \\
\hline 1 & متوسطة & I.Tr & r.rA & تمنتة المستقبل. لتقيم خدمات الإرشاد؛ لاختبار \\
\hline 0 & متوسطة & $1 . Y \varepsilon$ & $r . . V$ & لدعل الدخلفة، الجامعة على تتفيذ الزيارات لمواقع العمل \\
\hline r & متوسطة & 1.19 & $r . r)$ & تققدَّم خدمات الإرشاد المهني حول كيفية اتخاذ \\
\hline$r$ & متوسطة & I. & r.IV & 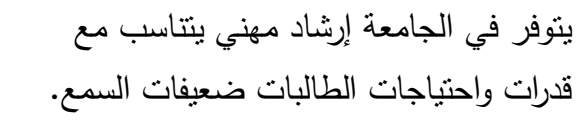 \\
\hline$\wedge$ & متوسطة & $1.2 \pi$ & r.10 & 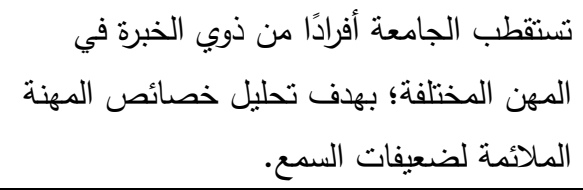 \\
\hline$\varepsilon$ & متوسطة & I.r. & $r . . \wedge$ & تقدريف الطرالبات بالمهن التربية جلسات إرشادية تهدف إلى تنتاسب مع \\
\hline v & متوسطة & $1 . r 0$ & r.9r & تحرص إدارة الجامعة على تقديم الإرشاد المهني \\
\hline
\end{tabular}




\begin{tabular}{|c|c|c|c|c|c|}
\hline & & & & المتنية للطصالبات والذي يساعد في تحديد الميول & \\
\hline 7 & متوسطة & $1 . r$. & $r . . r$ & تقدام الجامعة لائحة بنوعية الوظائف التي & $\wedge$ \\
\hline & متوسطة & $1 . . v$ & $r . \wedge$ & جة الكلية للبُعد الأول & \\
\hline
\end{tabular}

يتضح من الجدول السابق أن المتوسط الحسابي لبُعد(طرق تزويد الطالبات ضعيفات السمع بخدمات الارشاد المهني)لاى عينة الدراسة بلغ (1 . . ب)، وانحراف معياري بمقدار (V • ـ ( )، وبدرجة تحقق منوسطة.

بينما كانت الفقرة الأولى والتي تتص على:(تتوفر خطة لتقديم خدمات الارشاد لاختيار مهنة المستقبل) هي أكثر الفقرات شيوعًا، بمتوسط حسابي

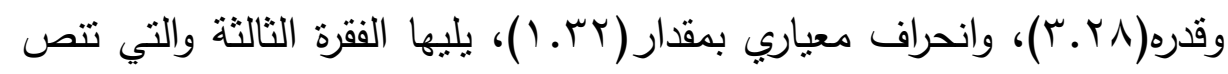

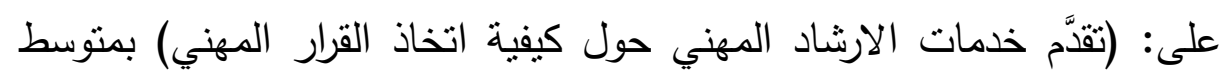
حسابي وقدره (1.Y.r)، وانحراف معياري بمقدار (9 (ـ ())، وفي المرتبة الثالثة جاءت الفقرة الرابعة والتي تتص على: (يتوفر في الجامعة ارشاد مهني ينتاسب مع قدرات واحتياجات الطالبات ضعيفات السمع) بمنتوسط حسابي وقدره

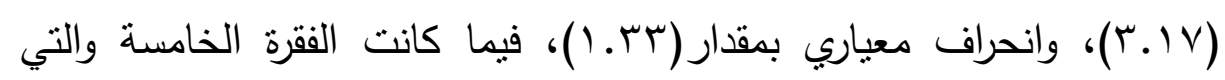
تتص على: (تستقطب الجامعة افرادًا من ذوي الخبرة في المهن المختلفة بهدف تحليل خصائص المهنة الملائمة لضعيفات السمع) هي أقل الفقرات شيوعًا،

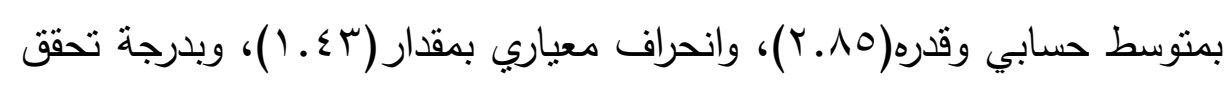
متوسطة لجميع الفقرات.

جدول (7)

المتوسطات الحسابية والانحرافات المعيارية للبعد الثاني:

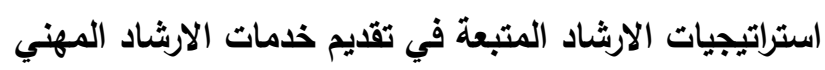


$(r \wedge=\dot{ن})$

\begin{tabular}{|c|c|c|c|c|c|}
\hline الترتيب & التحقق & 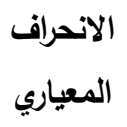 & المستوسط & الفقرات & \\
\hline$\varepsilon$ & منوسطة & $1 . r A$ & r. . 9 & 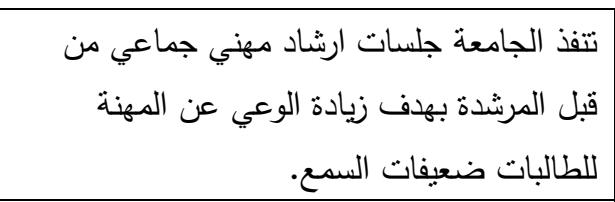 & 9 \\
\hline 1 & منخفضة & $1 . r 1$ & T.T. & متنفة المرشدة جلسات فردية حول كيفية اختيار & 1. \\
\hline 0 & متوسطة & 1.17 & r.VA & توضح كيفية اختيار المهنة. & 11 \\
\hline$r$ & منوسطة & $1 . r 1$ & $r . .1$ & 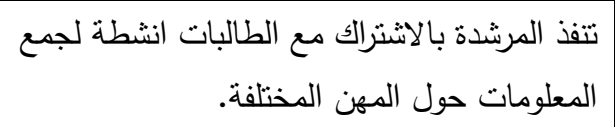 & IT \\
\hline 1 & متوسطة & 1.1 & r.l. & تحقف المرشدة حوارات حول المهن التي يمكن ان & $\pi$ \\
\hline r & متوسطة & 1.11 & $r . . v$ & الموفر الجامعة المعلومات المهنية عن منطلبات & $1 \varepsilon$ \\
\hline & متوسطة & 1.14 & r.91 & الدرجة الكلية للبعد الثاني & \\
\hline
\end{tabular}

يتضح من الجدول السابق أن المتوسط الحسابي لبعد (استراتيجيات الإرشاد المتبعة في تقديم خدمات الإرشاد) لاى عينة الدراسة بلغ (1) (ب.9)، وانحراف معياري بمقدار (r ( ـ ())، وبدرجة تحقق متوسطة.

وقد كانت الفقرة الثالثة عشر والتي تتص على: (تتفذ المرشدة حوارات حول المهن التي يمكن أن تحقق فيها الطالبات نجاحًا، والتي تنتاسب مع وله ميولهن) هي أكثر الفقرات شيوعًا، بمتوسط حسابي وقدره (•. (ب)، وانحراف 
معياري بمقدار( ( ـ ()، يليها الفقرة الرابعة عثر والتي تتص على: (توفر الجامعة

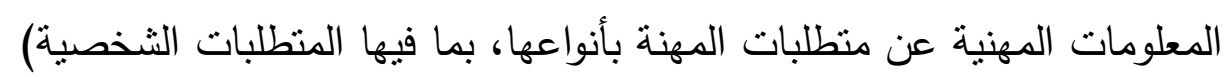

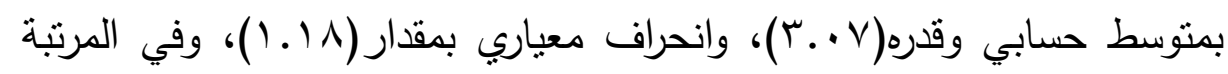

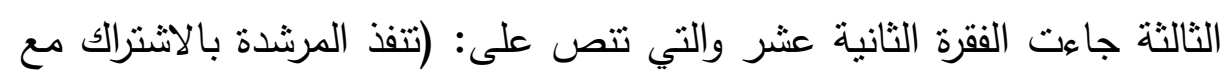
الطالبات أنشطة لجمع المعلومات حول المهن المختلفة) بمتوسط حسابي

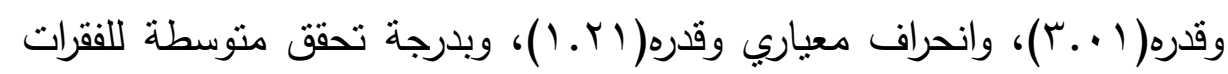
الثلاث، فيما كانت الفقرة العاشرة والتي تتص على: (تتفذ المرشدة جلسات فردية حول كيفية اختيار مهنة المستقبل للطالبة) هي أقل الفقرات شيوعًا، بمتوسط

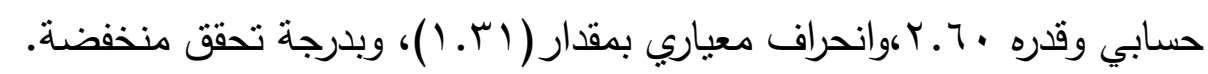

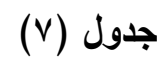

المتوسطات الحسابية والانحرافات المعيارية للبعد الثالث:

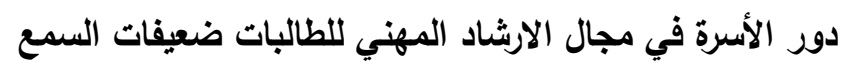

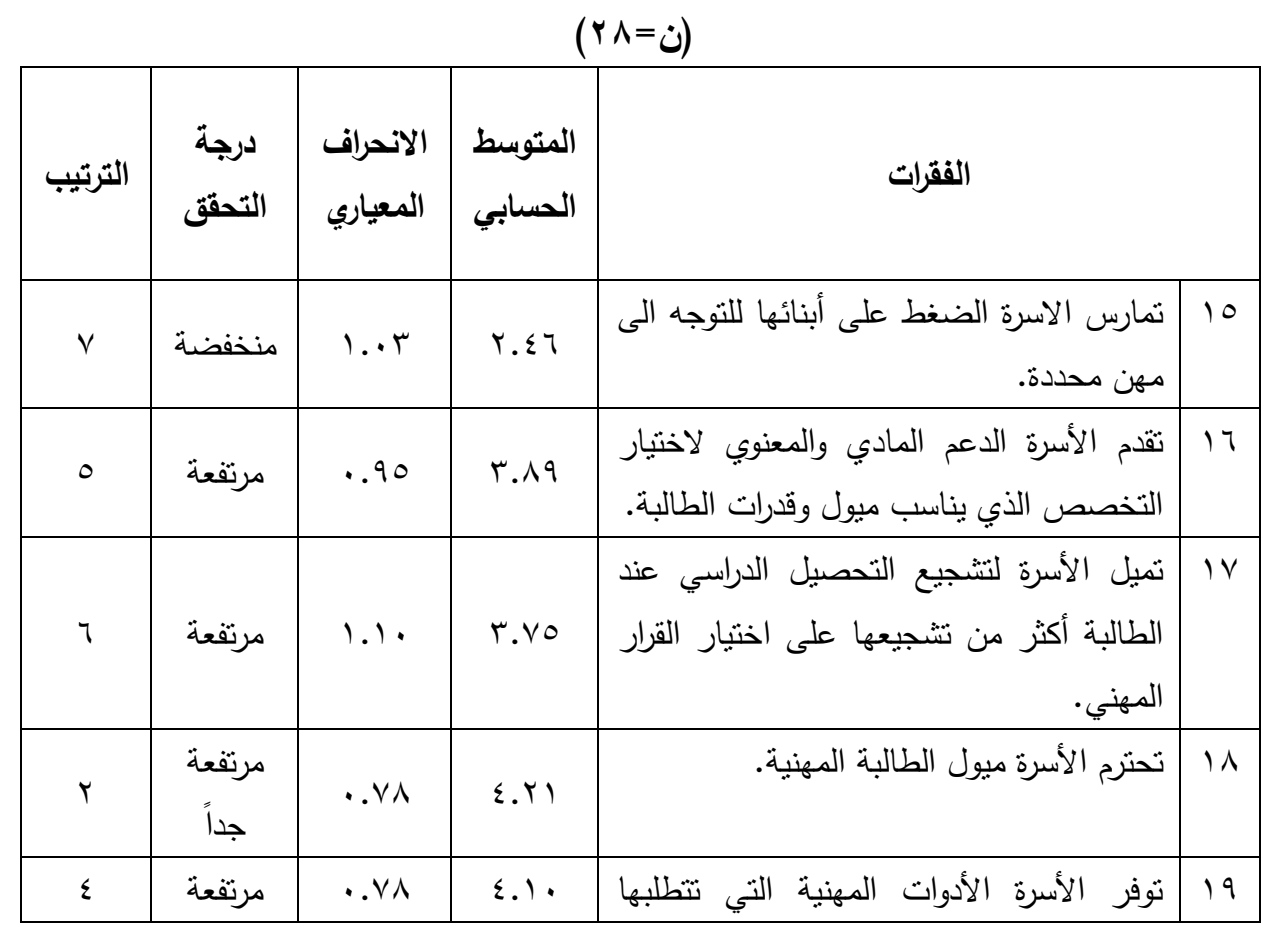




\begin{tabular}{|c|c|c|c|c|c|}
\hline & & & & بعض الهوايات المفضلة. & \\
\hline 1 & مرتفعة & $\cdot . \wedge 1$ & E.MT & 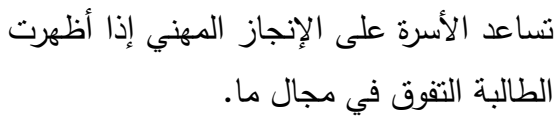 & $r$. \\
\hline$r$ & مرتفعة &.$V V$ & E.IV & 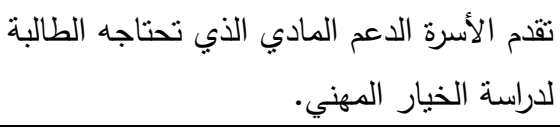 & r) \\
\hline & مرتفعة & $.7 r$ & 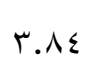 & الدرجة الكلية للبعد الثالث & \\
\hline
\end{tabular}

يتضح من الجدول السابق أن المتوسط الحسابي لبعد(دور الأسرة في مجال الإرشاد المهني للطالبات ضعيفات السمع)لاى عينة الدراسة بلغ (عــ؟ب)، وانحراف معياري بمقدار (r7. · )، وبدرجة تحقق مرتفعة.

وقد كانت الفقرة العشرون والتي تتص على: (تساعد الأسرة على الإنجاز المهني إذا أظهرت ابنتهم التقوق في مجال ما) هي أكثر الفقرات شيوعًا،

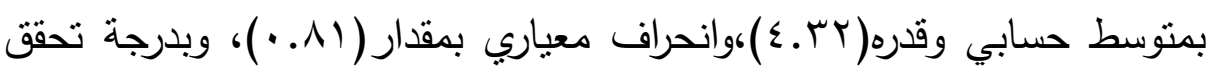
مرتفعة جدًا، تليها الفقرة الثامنة عشر والتي تتص على: (تحترم الأسرة ميول

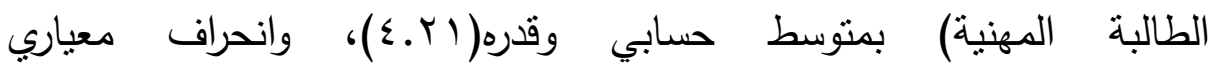

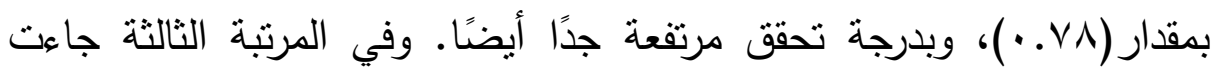
الفقرة الحادية والعشرون والتي تتص على: (تقدم الأسرة الدعم المادي الذي لهي تحتاجه الطالبة في دراسة الخيار المهني) بمتوسط حسابي وقدره(VV)؛ ( V)؛ وانحراف معياري وقدره(VV. • ·)، وبدرجة تحقق مرتفعة. فيما كانت الفقرة الخامسة عشر والتي تتص على:(تمارس الأسرة الضغط على أبنائها للتوجه إلى مهن

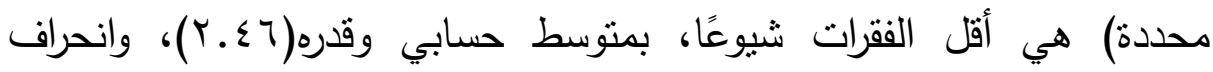
معياري بمقدار (r +. (1)، وبدرجة تحقق منخفضة.

جدول (^)

المتوسطات الحسابية والانحرافات المعيارية للبعد الرابع:

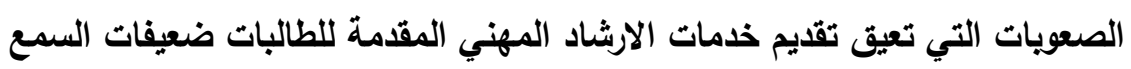


$(r \wedge=\dot{ن})$

\begin{tabular}{|c|c|c|c|c|c|}
\hline الترتيب & التحقق & 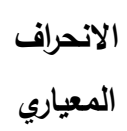 & المستوسط & الفقرات & \\
\hline 0 & متوسطة & $1 . r 9$ & r. . 9 & اليوجد وسائل نقل كافية لزيارة مواقع العمل & rr \\
\hline$\varepsilon$ & متوسطة & $1.1 Y$ & $r$ & المن الصعب استقطاب خبير لنقديم الارشاد & $r$ \\
\hline r & مرتفعة & $1 . . r$ & T.AT & 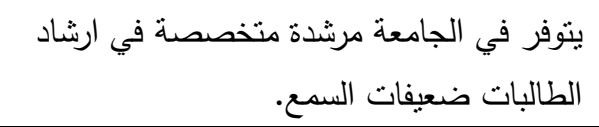 & $r \varepsilon$ \\
\hline 1 & مرتفعة &. .99 & r.A9 & بتوفر في مكتبة الجامعة مراجع علمية كافية عن & ro \\
\hline 7 & منخفضة & I.T. & T. $\{Y$ & بشبب تشخل الأهل عائقًا في إجراءات الارشاد المهني & $r T$ \\
\hline$r$ & متوسطة & $1 . .7$ & r.rq & تضكل النظرة الدونية لـفهوم التعليم المهني & $r v$ \\
\hline & متوسطة &.$\wedge r$ & T.T & الدرجة الكلية للبعد الرابع & \\
\hline
\end{tabular}

يتضح من الجدول السابق أن المتوسط الحسابي لبعد (الصعوبات التي

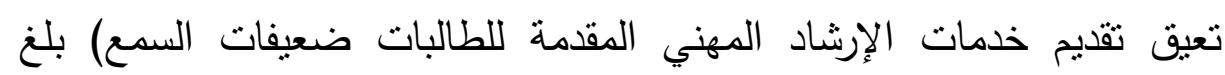

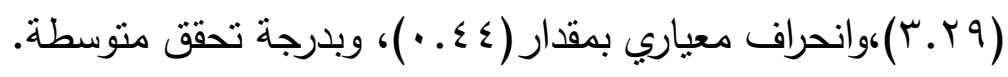

وقد كانت الفقرة الخامسة والعشرون والتي تتص على: (يتوفر في مكتبة الجامعة مراجع علمية كافية عن الإرشاد المهني) هي أكثر الفقرات شيوعًا، لئهي

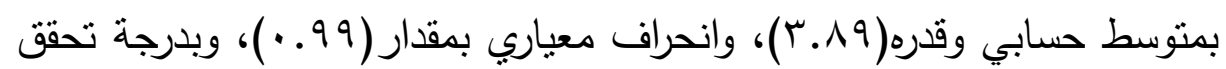

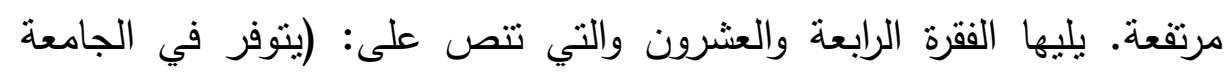
مرشدة متخصصة في إرشاد الطالبات ضعيفات السمع) بمتوسط حسابي 
وقدره(r. المرتبة الثالثة جاءت الفقرة السابعة والعشرون والتي تتص على: (تشكّل النظرة الدونية لمفهوم التعليم المهني صعوبة تحول دون تتفيذ موضوع الإرشاد المهني

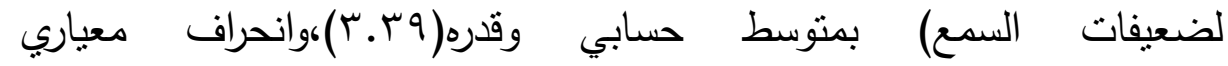
وقدره( T + ـ ()،وبدرجة تحقق متوسطة. فيما كانت الفقرة السادسة والعشرون والتي تتص على:(يشكل الأهل عائقًا في إجراءات الإرشاد المهني بسبب تدخلهم في تحديد مهنة المستقبل للطالبة) هي أقل الفقرات شيوعًا بمتوسط حسابي

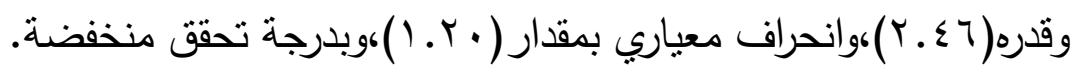

جدول (9) (9)

المتوسطات الحسابية والانحرافات المعيارية لأبعاد المحور الأول: دور خدمات الإششاد المهني المقدمة للطالبات ضعيفات السمع لابعات $(r \wedge=\dot{0})$

\begin{tabular}{|c|c|c|c|c|c|}
\hline الترتيب & التحقق & المعياري & الحسابي & \multicolumn{2}{|l|}{ الأبعاد } \\
\hline r & منوسطة & $1 . . v$ & $r . . \wedge$ & البعد الأول & 1 \\
\hline$\varepsilon$ & متوسطة & 1.15 & r.91 & البعد الثاني & Y \\
\hline 1 & مرتفعة &. .79 & 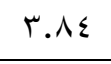 & البعد الثالث & $r$ \\
\hline r & منوسطة &.$\Delta r$ & r.rq & 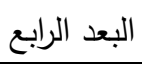 & $\varepsilon$ \\
\hline & متوسطة & $\cdot . \wedge 1$ & T.TV & \multicolumn{2}{|c|}{ الدرجة الكلية للمحور الأول } \\
\hline
\end{tabular}

يتضح من الجدول السابق أن المتوسط الحسابي لواقع خدمات الإششاد المهني للطالبات ضعيفات السمع بلغ(r.r.r) وانحراف معياري بمقدار( ( I. •) وبدرجة تحقق منوسطة. 
وتعزو الباحثان هذه النتيجة إلى أن الطالبات ضعيفات السمع لا يتلقين

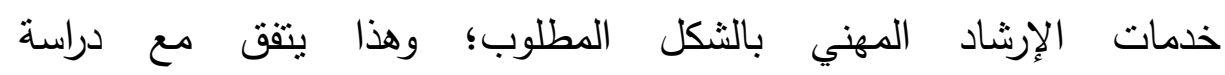

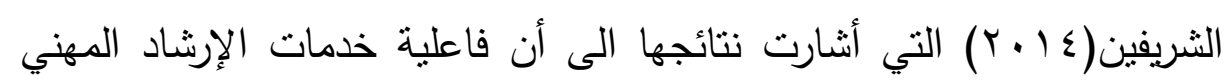

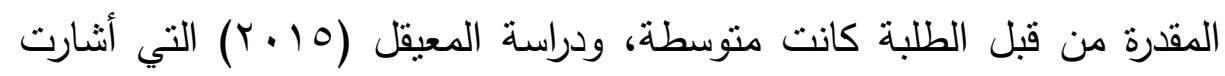

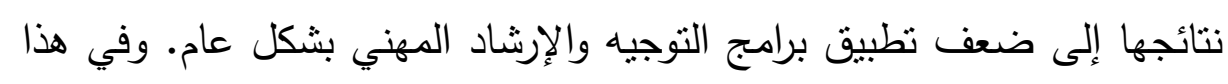

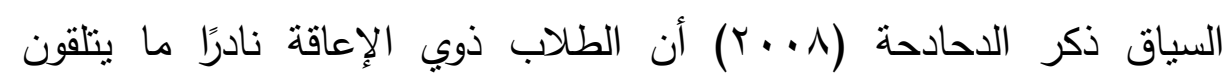
الخدمات الإرشادية المهنية الداعمة على الوجه المطلوب.

Murugami\&Nel وهو ما أظهرته نتائج دراسة موريجامي ونيل

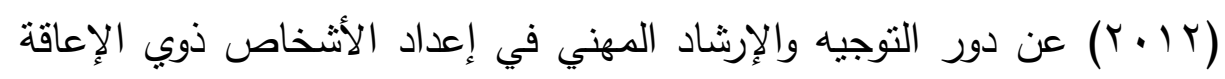

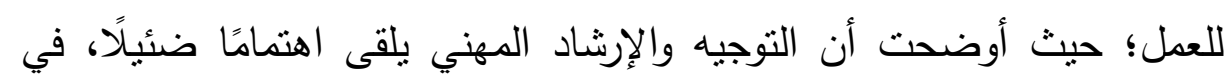

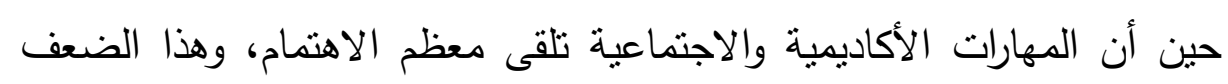

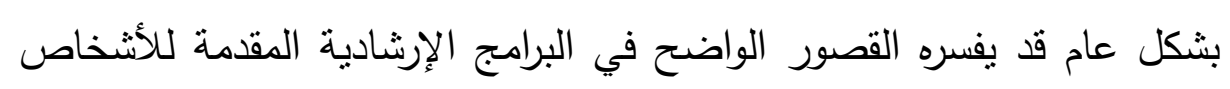
ذوي الإعاقة مقارنة بالخدمات التنربوية الأخرى.

وقد كان بعد: (دور الأسرة في مجال الإرشاد المهني لضعيفات السمع)

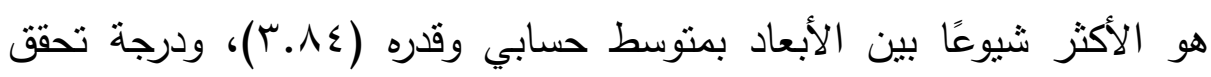

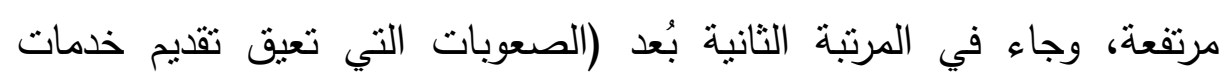

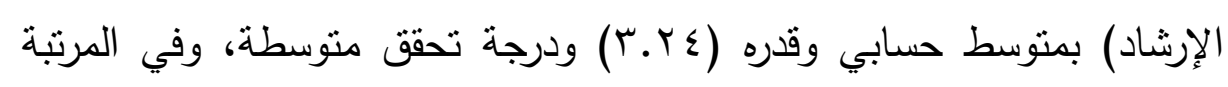

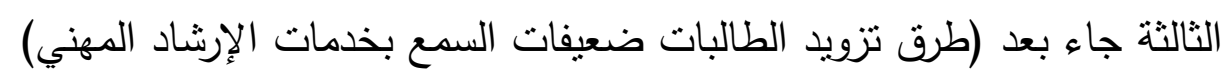

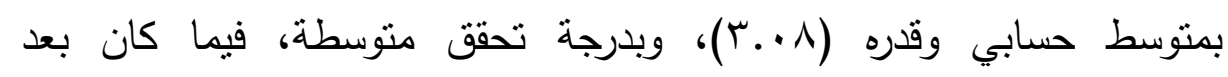

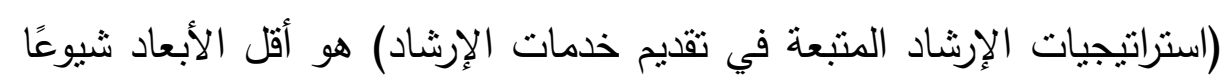
بمتوسط حسابي وقدره (Y.9.4)، ودرجة تحقق متوسطة أيضًا. 
وثُرجح الباحثنان سبب حصول بعد (دور الأسرة في مجال الإرشاد

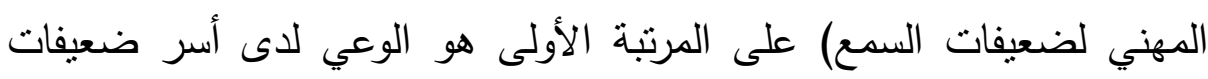

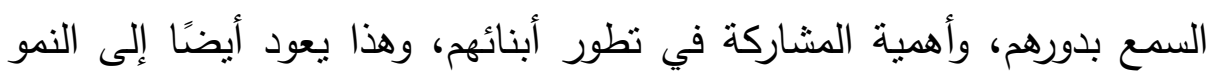

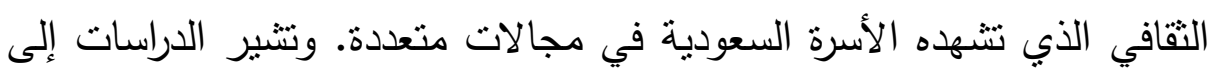

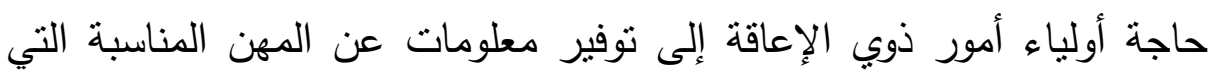

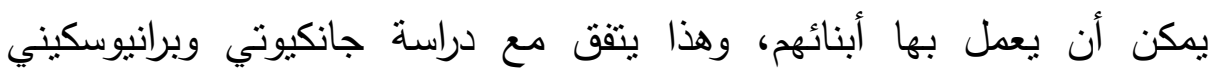
Jankute \& baranauskiene(Y. Y T)

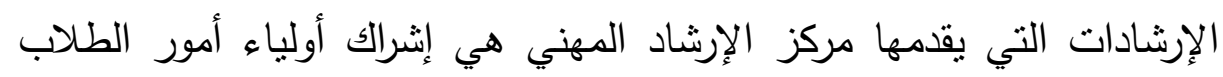
ذوي الإعاقة في النشاطات المهنية.

أما حصول بُعد(الصعوبات التي تعيق تقديم خدمات الإرشاد المهني)

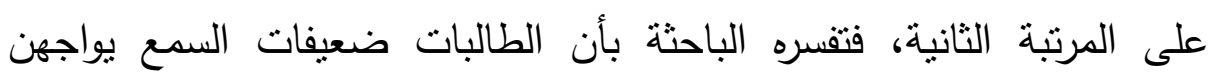

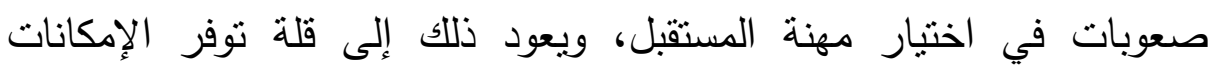

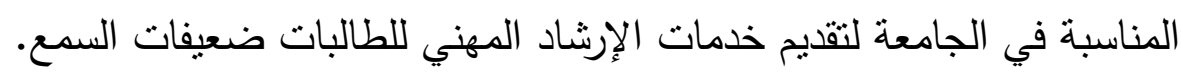
وهذا يتفق مع دراسة غنيم(؟ (Y) التي كثفت نتائجها أن أبرز

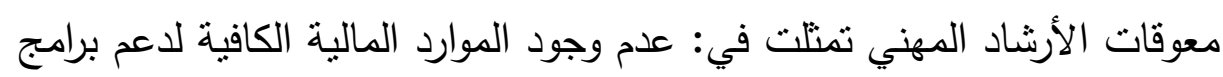

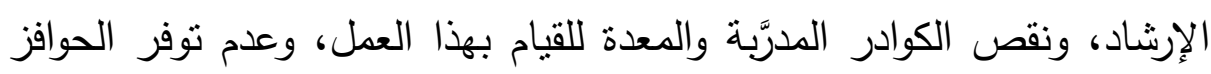

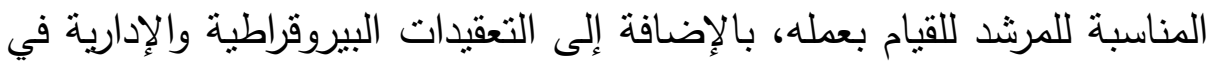
المدرسة، وقلة توفر الإمكانات المناسبة في المدراس للقيام بالأنشطة الإرشادية،

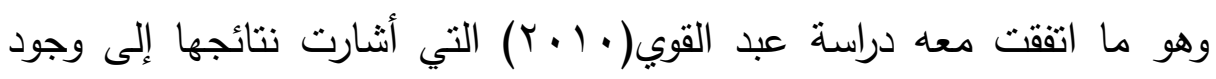

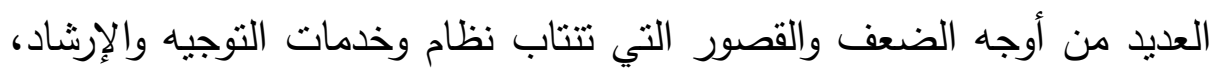

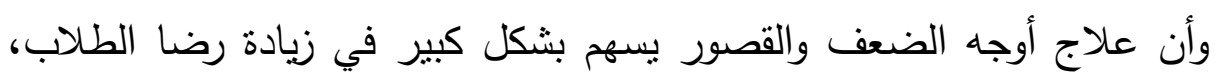

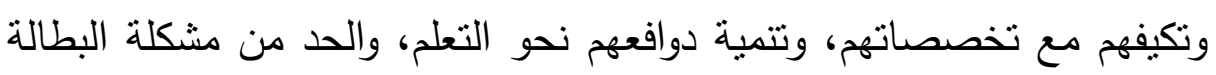


أما حصول بُعد (طرق تزويد الطالبات ضعيفات السمع بخدمات الإرشاد

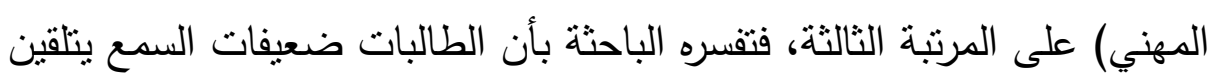

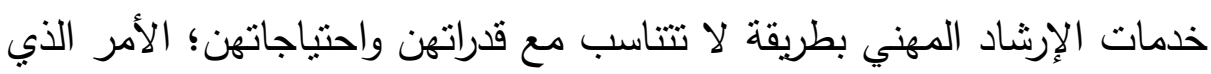

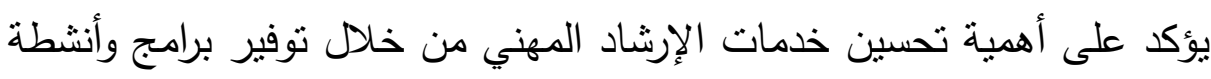

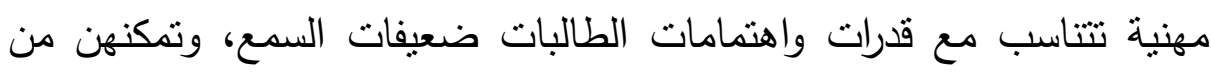

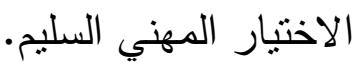

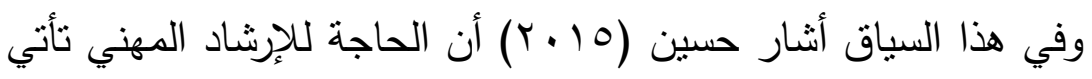

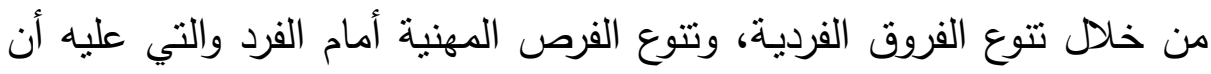

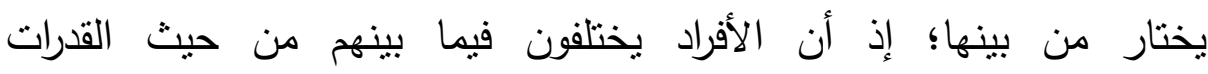
والاستعدادات والميول وخصائص الثخصية، وعلى الطرف الآخر نوجد مهن وتخصصات كثيرة ومتنوعة تتطلب من الفرد التعرف على هذه المهن، وما

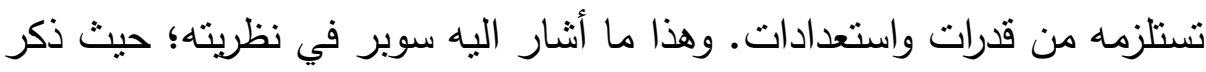

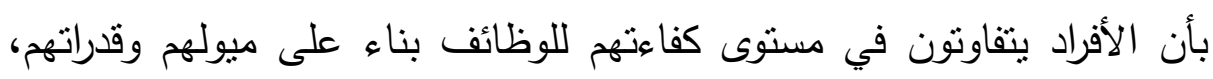
فالفرد يكون أكثر كفاءة في الوظيفة التي تطابق ميوله وقدراته.

أما حصول بُعد(استراتيجيات الإرشاد المهني المتبعة في تقديم خدمات

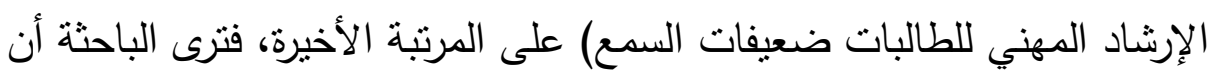

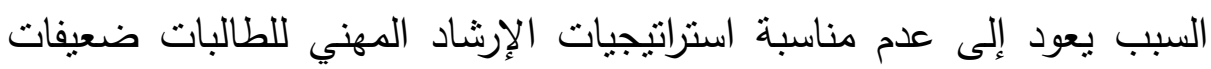

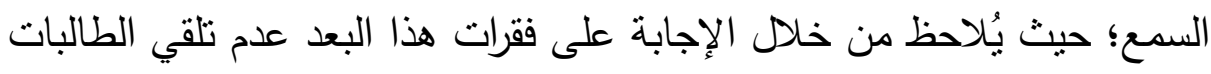

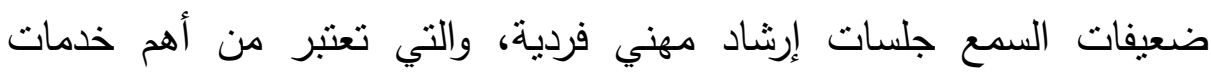
الإرشاد المهني؛ حيث تقوم الجلسات الفردية بتقديم معلومات مهنية، وتعريف الطالبة بنفسها وقدراتها، ومساعدتها في اختيار المهنة المناسبة لها، والتخطيط التهات

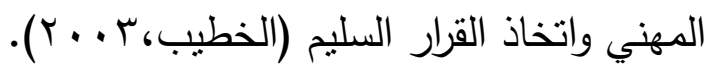


وللإجابة على السؤال الفرعي الثاني والذي ينص على:"ما مستوى رضا ضعيفات السمع عن دور الإرشاد المهني في تأهيلهن لسوق العمل في مدينة جدة؟"

قامت الباحثتان باستخراج المتوسطات الحسابية، والانحرافات المعيارية للمحور الثاني في المقياس، وكانت النتائج كما يلي: باسن

$$
\text { جدول (·) }
$$

المتوسطات الحسابية والانحرافات المعيارية للمحور الثاني:

مستوى رضا ضعيفات السمع عن دور الارشاد المهني

\begin{tabular}{|c|c|c|c|c|c|}
\hline \multicolumn{6}{|c|}{$(r \wedge=\dot{U})$} \\
\hline الترتيب & 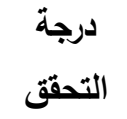 & 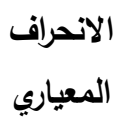 & المتوسط & الفقرات & \\
\hline 0 & منوسطة & $1.1 \pi$ & r.VA & 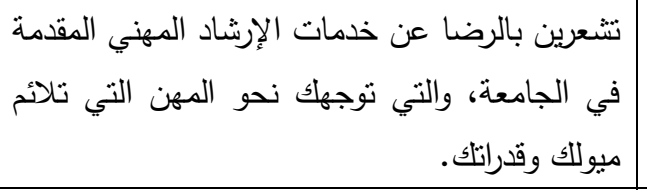 & 1 \\
\hline r & مرتفعة & $1 . . r$ & $r . \varepsilon r$ & | يساهم الإرشاد المهني في الجامعة بزيادة فرص & $r$ \\
\hline$r$ & مرتفعة &. .99 & $r . \varepsilon r$ & حول مهنتلك المستقبلية. الإنساد المهني يشعرك بالرضا & $r$ \\
\hline 1 & مرتفعة &. .91 & $\varepsilon$ & نتجدين صعوبة في اتخاذ القرار المهني المناسب & $\varepsilon$ \\
\hline 7 & مرتفعة &. .17 & r...V & |لتعرين بعدم الرضا نتيجة لعدم امتلاك المرشدة & 0 \\
\hline$\varepsilon$ & منوسطة & 1.17 & r.ru & تتشعرين بالرضا لأن الارشاد المهني في الجامعة & 7 \\
\hline
\end{tabular}




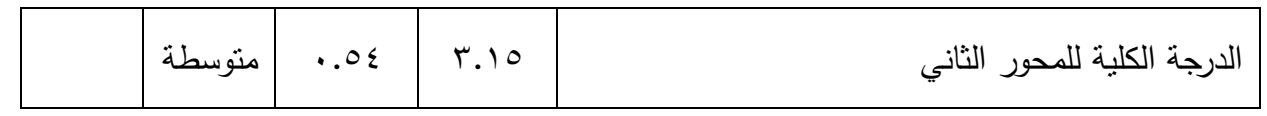

يتضح من الجدول السابق أن المتوسط الحسابي لمستوى(رضا ضعيفات السمع عن الخدمات الإرشاد المهني المقدمة لهن) بلغ(0 1.ب)، وانحراف معياري بمقدار ( §ه. • )، وبدرجة تحقق متوسطة.

بينما كانت الفقرة الرابعة والتي تتص على:(تجدين صعوبة في اتخاذ القرار المهني المناسب نتيجة غياب الإرشاد المهني المتخصص) هي أكثر الفقرات شيوعًا بمتوسط حسابي وقدره (ع)، وانحراف معباري بمقدار (^^. • )، تلبها الفقرة الخامسة والتي تتص على: (تشعرين بعدم الرضا نتيجة لعدم امتلاك المرشدة الوعي الكافي بقدراتك وميولك المهنية) بمتوسط حسابي وقدره (r9. ب)، وانحراف معياري بمقدار (T . . )، وفي المرتبة الثالثة جاءت الققرة الثانية والتي تتص على: (يساهم الإرشاد المهني في الجامعة بزبادة فرص التقدم المهني والأكاديمي) بمتوسط حسابي وقدره(سء.ب)، وانحراف معياري بمقدار (ب . (1)، وبدرجة تحقق مرتفعة للفقرات الثناث. فيما كانت الفقرة الأولى والتي تتص على:(تشعرين بالرضا عن خدمات الإرشاد المهني المقدمة في الجامعة والتي توجهك نحو المهن التي تلائم ميوللك وقدراتك) هي أقل الفقرات شيوعاً بمتوسط

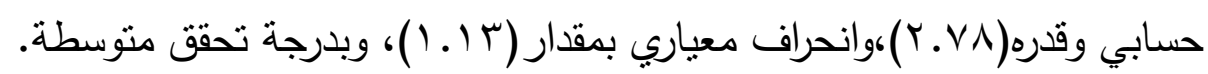
وتعزو الباحثة هذه النتيجة إلى عدم رضا الطالبات ضعيفات السمع عن خدمات الإرشاد المهني المقدمة لهن في الجامعة، ورغبتهن في تلقي خدمات الإرشاد المهني بصورة أفضل؛ حتى يتمكنً من اختيار المهنة المناسبة لهن، ويعود ذلك إلى عدة عوامل منها عدم وجود مرشدة متخصصة لضعيفات السمع في هذا المجال. وفي هذا الإطار أثارت نيسان (9 . . r) أن أكبر العقبات التي تواجه خدمات التأهيل المهني هي نقص الموظفين المدربين. 
بالإضافة الى قلة البرامج التي تقدمها الجامعة للطالبات ضعيفات

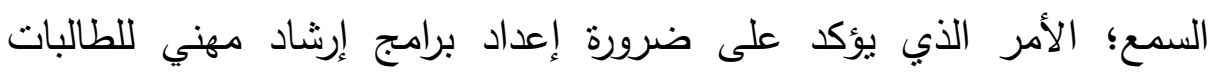
ضعيفات السمع في الجامعة تعمل على مساعدتهن في اختيار المهنة المناسبة، وإعدادهن وتأهيلهن للعمل بها.

وقد أنتتت هذه البرامج فعاليتها كما في دراسة ستوك وآخرون Stock et

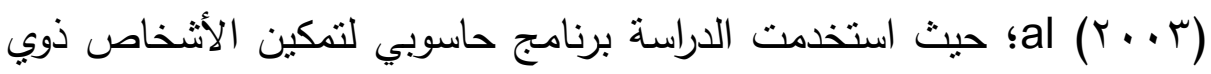

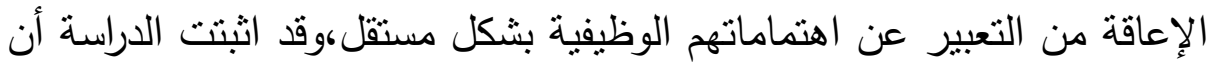

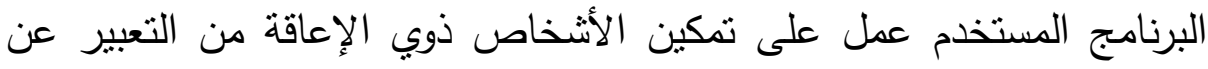
الأعمال التي يفضلونها باستقلالية، وحستن من أنشطة المطابقة المهنية، كما رأى المعلمون والمرشدون أن البرنامج المستخدم في الدراسة كان قادرًا على نقديم

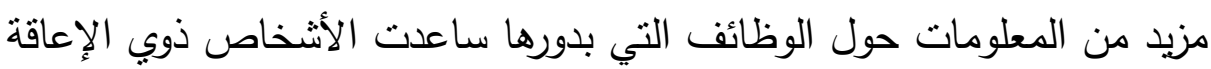

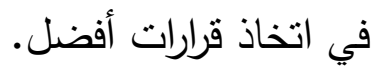

وفي هذا السياق أكد المهيري وآخرون(1) +r) بأن البرامج المهنية

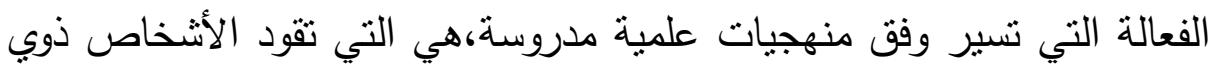
الإعاقة إلى النجاح في سوق العمل؛ لأنها تتناغم مع منطلباته والتطورات

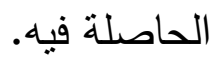

وللإجابة على السؤال الفرعي الثالث والذي ينص على:"هل توجد فروق دالة إحصائيًا في مسنوى رضا الطالبات ضعيفات السمع عن خدمات الإرشاد المهني لتأهيلهن لسوق العمل في مدينة جدة، باختلاف التخصص الدراسي(علوم إدارية، رسم وفنون)". 
قامت الباحثنان باستخدام اختبار مان وتتي Mann-Whiteny اللابارامنري للعينات المستقلة؛ بهدف التعرف على دلالة الفروق في درجات مقياس واقع الخدمات الإرشادية المقدمة لضعيفات السمع، وجاءت النتائج كما يلي: جلول (11)

نتائج اختبار مان وتني لدلالة الفروق بين متوسطات درجات المقياس بأبعاده تبعاً لمتغير التخصص الدراسي لفي

\begin{tabular}{|c|c|c|c|c|c|c|c|c|}
\hline \multicolumn{9}{|c|}{$(r \wedge=\dot{U})$} \\
\hline \multicolumn{2}{|c|}{ مستوى الدلالة } & قيمة & مجموع & المتوسط & العدد & المجموعات & \multicolumn{2}{|c|}{ الأبعاد } \\
\hline \multirow{2}{*}{ غير دالة } & \multirow{2}{*}{.$r r$} & \multirow{2}{*}{$1 . r}$. & $r \varepsilon . .0$ & $10 . \leqslant 1$ & r & رسم وفنون & \multirow{2}{*}{ الأول } & \\
\hline & & & 70.0 & $1 . .9 r$ & 7 & علوم إدارية & & \\
\hline \multirow{2}{*}{ غير دالة } & \multirow{2}{*}{.14} & \multirow{2}{*}{$1.0 \varepsilon$} & $r \leqslant 7.0$ & 10.10 & rr & رسم وفنون & \multirow{2}{*}{ الباني } & \\
\hline & & & 09.0 & 9.94 & 7 & علوم إدارية & & \\
\hline \multirow{2}{*}{ غير دالة } & \multirow{2}{*}{.90} & \multirow{2}{*}{. .0} & W1 & $1 \leqslant . \leqslant 0$ & Mr & رسم وفنون & \multirow{2}{*}{ الثالث } & $\overline{3}$ \\
\hline & & & $\wedge \wedge$ & $1 \leqslant .7 V$ & 7 & علوم إدارية & & হুন্ত \\
\hline \multirow{2}{*}{ مستوى د. مالة عند } & \multirow[b]{2}{*}{$\cdots r$} & \multirow[b]{2}{*}{ T.YY } & ron & 17.4. & Tr & رسم وفنون & \multirow[b]{2}{*}{ البعد الرابع } & \\
\hline & & & $\varepsilon V$ & V.9r & 7 & علوم إدارية & & \\
\hline \multirow{2}{*}{ غير دالة } & \multirow{2}{*}{$\cdots v$} & \multirow{2}{*}{1.199} & rol & 10.90 & YY & رسم وفنون & \multirow{2}{*}{ المحور } & \\
\hline & & & 00 & $9.1 \mathrm{~V}$ & 7 & علوم إدارية & & \\
\hline غير دالة & $\cdot . \leqslant 7$ &.$V r$ & Trm & $10 . .9$ & Yr & رسم وفنون & & \\
\hline
\end{tabular}




\begin{tabular}{|c|c|c|c|c|c|c|}
\hline مستوى الدلالة & $\begin{array}{c}\text { قيمة } \\
Z\end{array}$ & مجموع الرتب & المتتوسط & العدد & المجموعات & الأبعاد \\
\hline & & $V \varepsilon$ & Tr.Tו & 7 & علوم إدارية & المحور الثاني \\
\hline
\end{tabular}

يوضح الجدول السابق عدم وجود فروق ذات دلالة إحصائية في منوسطات درجات واقع خدمات الإرشاد المهني لضعيفات السمع بأبعاده تبعًا

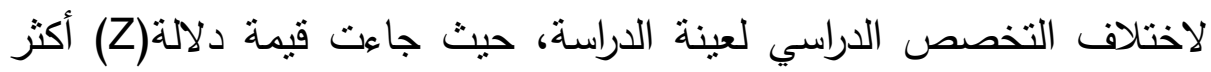
من(0...)، فيما عدا بُعد (استراتيجيات الإرشاد المهني المقدم للطالبات ضعيفات السمع) فقد وجدت دلالة فروق بين المجموعتين لصالح طالبات قسم

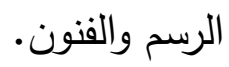

وتقسر الباحثتان هذه النتيجة بأن خدمات الإرشاد المهني المقدمة للطالبات ضعيفات السمع في قسم الرسم والفنون، وقسم العلوم الإدارية يتلقين نفس خدمات الإرشاد المهني، باستثناء الاختلاف في الاستراتيجيات المتبعة؛

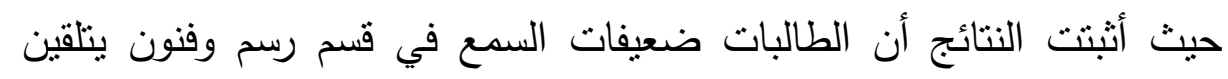
الإششاد المهني من خلال استراتيجيات أفضل من تلك المقدمة للطالبات ضعيفات السمع في قسم العلوم الإدارية، ويعود ذللك إلى عدة عوامل منها:عدم

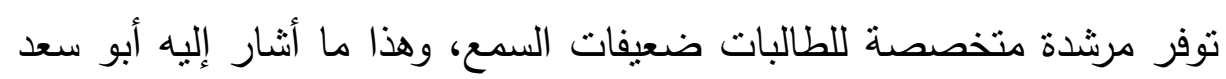

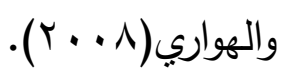

\section{توصيات الاراسة ويحوث مقترحة}

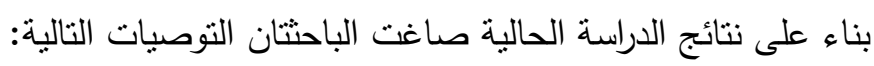
1-رفع مستوى تطبيق برامج الإرشاد المهني للطلاب ذوبي الإعاقة لـابة والاستعانة بالمختصين في هذا المجال

r-تدريب المرشدين في الجامعات على تقديم برامج التوجيه والإرشاد المهني للأشخاص ذوبي الإعاقة. 
r-تنظيم زيارات ميدانية والتثريب في العطلات الصيفية للطلاب ذوبي

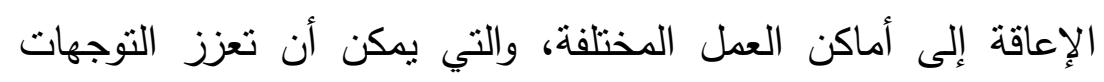

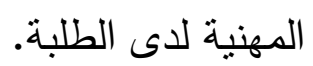

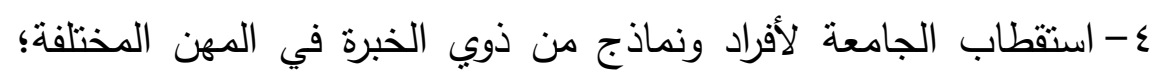
بهدف إرشاد الطلاب ذوي الإعاقة لاختيار المهن المناسبة لهم. 0- إنشاء مركز للإرشاد المهني في الجامعات متخصص في عمل برامج متكاملة للإرشاد المهني لجميع الطلاب في الجامعة. وكذلك اقترحت الباحثة عدة دراسات تتعلق بنتائج الدراسة وهي: 1- فعالية برنامج إرشادي مهني للطالبات ذوات الإعاقة في جامعة الملك

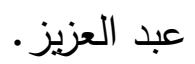
r- معوقات برامج الإرشاد المهني المقدمة للأشخاص ذوي الإعاقة في

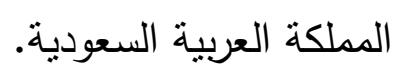
ب- واقع الإرشاد المهني في الجامعات الأهلية بمدينة جدة.

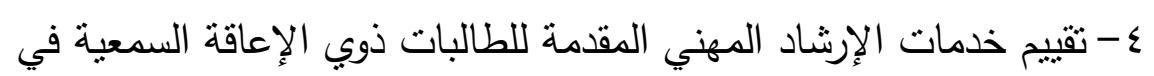

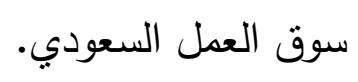
0- الحاجات المهنية لدى الأشخاص ذوبي الإعاقة السمعية في بعض مدن

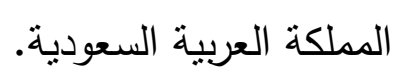

\section{المراجع:}

ا- المراجع العربية

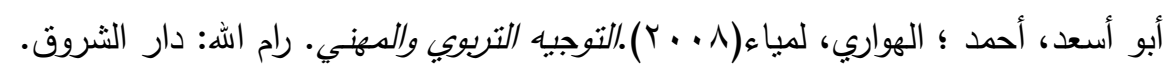




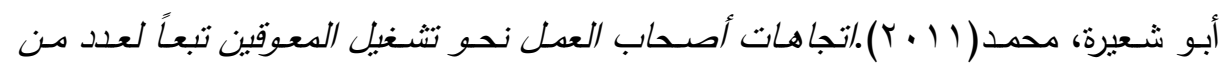
المتغيرات ، كلية التربية، جامعة الملك عبدالعزيز .

حسين، طه عبد العظيم (10 • ب).الإشاد النفسي-/لنظرية-التطبيق-النكنلوجيا .طV،عمان: دار الفكر.

الحوارنة، إياد نايف (ع ( + ب). فاعلية برنامج توجيه مهني في تحسين الفعالية الذاتية المهنية

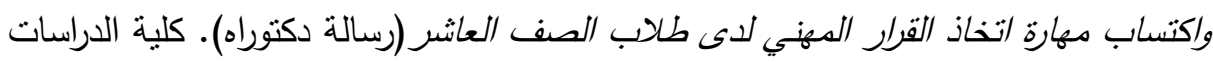
العليا، جامعة العلوم الإنسلامية العالمية.

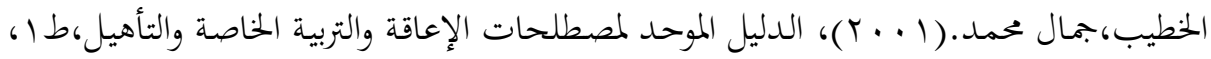

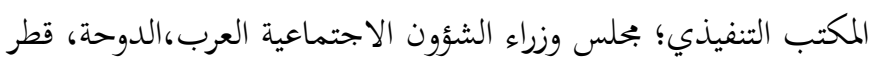

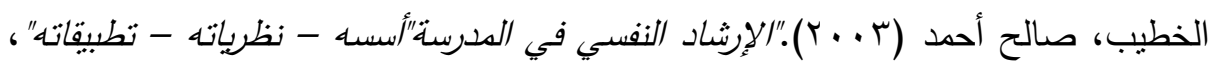

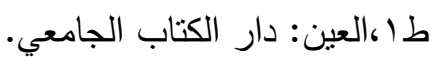

الدحادحه، باسم محمد (^ + +ץ). دراسة مقارنة للحاجات المهنية لدى طلبة الحالات الخاصة والطلبة العاديين في جامعة السلطان قابوس بسلطنة عمان في ضوء بعض دأن المتغيرات

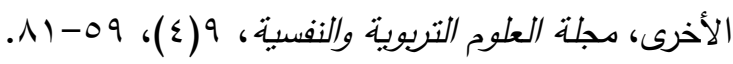

الزارع، نايف بن عابد (10 ب):تأهيل ذوي الاحتياجات الخاصة، ط7،عمان: دار الفكر.

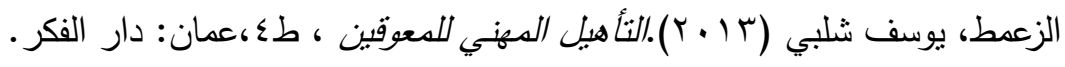

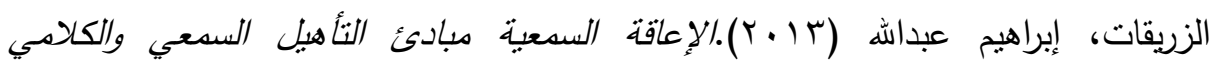
والتنربوي، طب،عمان: دار الفكر •

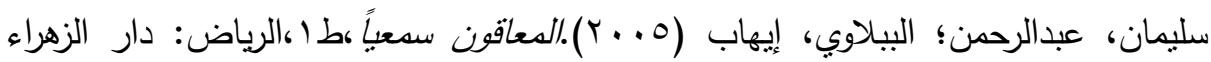
للنشر والتوزيع. 
سيد ، وليد فاروق حسن.(7 ( ץ)، دراسة للتعرف على اساليب تقويم برامج التأهيل المهني لذوى

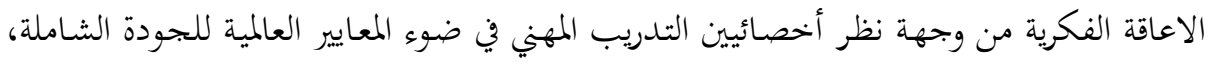

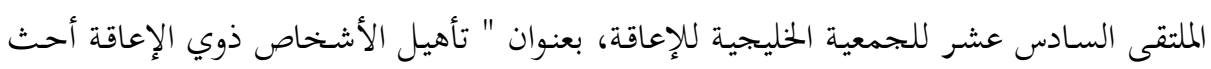

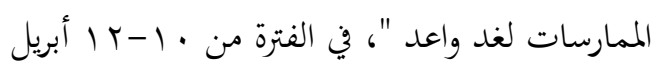

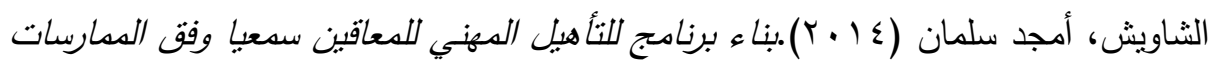

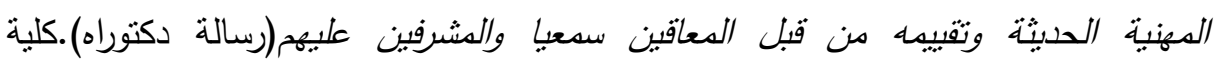
الدراسات العليا ، جامعة العلوم السلامية العالمية.

الشريفين، أحمد (ع (ب).فاعلية خدمات الإششاد المهني وقلق المستقبل المهني والعلاقة

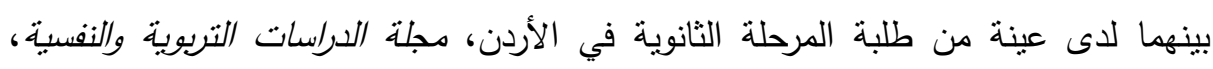
. $\Sigma 9 \cdot-\varepsilon \vee \varepsilon_{6}(r) \wedge$

الصيادي، منى علي (Y ب).الاغتراب النفسي لدى العاطلات عن العمل في ضوء حاجاتهن البى الإشاد المني (رسالة ماجستير).كلية التربية ،جامعة طيبة.

عبد القوي، أثرف بهجات (• ( ب).دليل مقترح للتوجيه والإرشاد المهني للطلاب الملتحقين

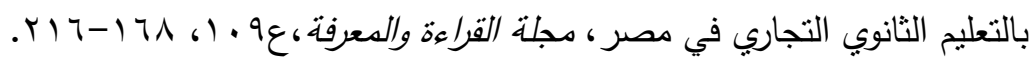
عبيد، ماجدة ( . . ب). مقدمة في تأهيل الدعاقين، طا، بمان: دار صفاء للنشر والتوزيع.

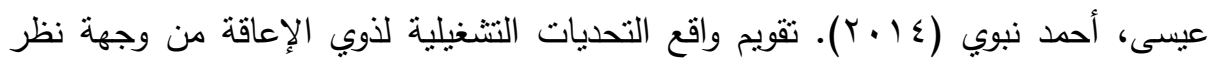

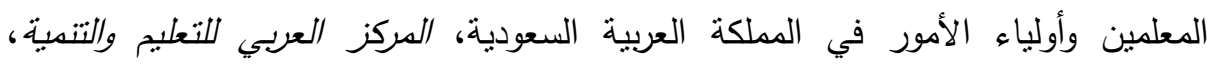
.rVI-190،(19)r)

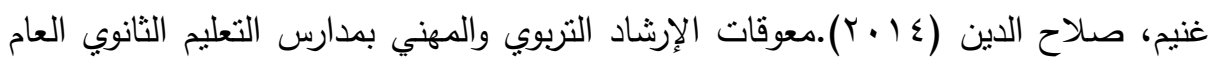

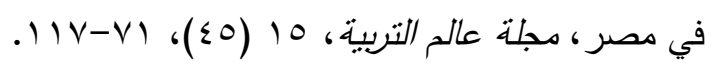




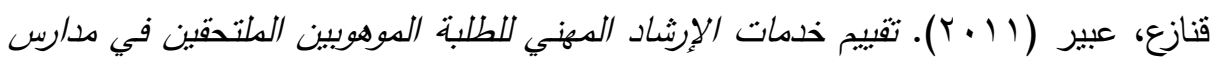

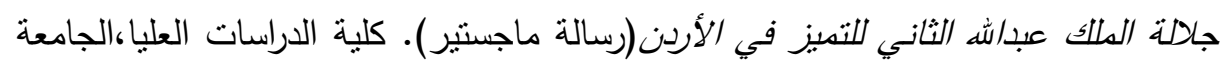
الأردنية.

القريوتي، يوسف (0. . ب).خدمات الانتقال، مؤتمر التربية الخاصة العربي الواقع والمأمول، عمان، الأردن. - مان.

مغربي، مكي محمد (ع ( ب).الصعوبات التي تواجه المعاقين سمعيا أثناء التأهيل المني

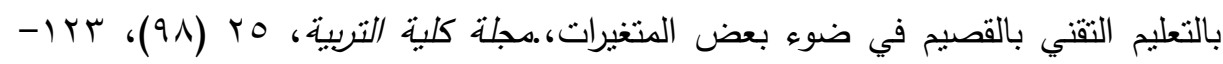
. $) \leqslant V$

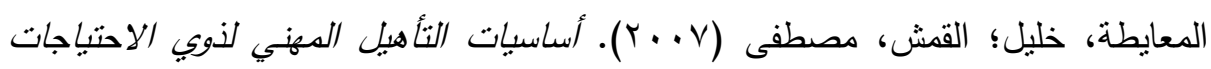

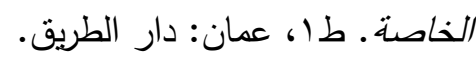

المعيقل، إبراهيم عبدالعزيز (0 ( • ب).واقع برامج التوجيه والإرشاد المهني ومعوقاتها بمعاهد وبرامج التربية الفكرية بمدينة الرياض من وجهة نظر العاملين بها، مجلة التربية

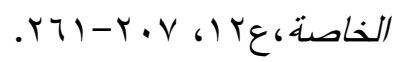

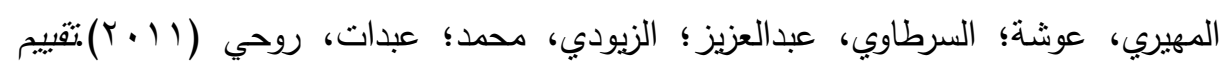

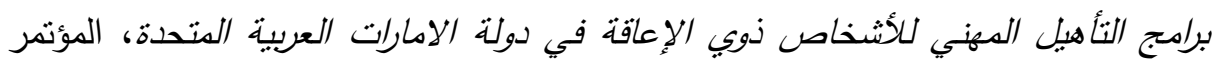
السنوي السادس عشر للإرشاد النفسي بجامعة عين شمس، لإسل القاهرة، مصر.

نيسان، خالدة عامر (9 . . ب).الإعاقة السهعية من مفهوم تأهيلي، طا، عمان: دار أسامة للنشر هلال، أسماء (9 . . ب)تأهيل الدعاقين، ط (،عمان:دار المسيرة للنشر والتوزيع.

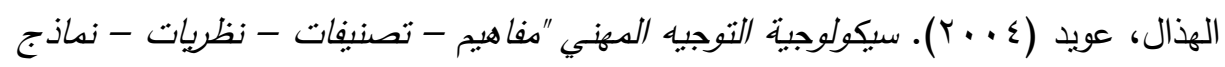

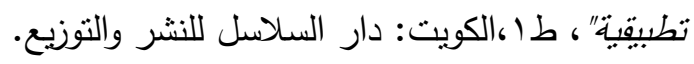




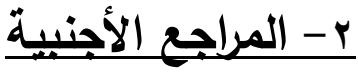

Abuzinadah, N., Malibari, A., and Krause, P. ( $(\cdot \mid \vee \vee)$.

Towards empowering hearing impaired students' skills in computing and technology. International Journal of Advanced Computer Science and Applications, (1), $1 \cdot v_{-} \mid 11$.

Burkhauser,R.( $(r \cdot \mid))$.Effect of postsecondary education on the economic statues of person who are deaf of hard of hearing. Journal of deaf studies and deaf education, $17(\varepsilon), r$ ro- $r \varepsilon$.

Cocks, E \& Thoresen, S\& Lewis, G.(Y+|1).Successful approaches to placing and supporting apprentices and trainees with disability in Australia, Journal of vocational Rehabilitation, $\Gamma \varepsilon(\Gamma), 1 \wedge 1-1 \wedge 9$.

Gysbers,N.,\& Happener, M \& Johnston. $\left(Y \ldots{ }^{9}\right)$. Career Counseling "Context, Processes, and Techniques", American counseling association 0999 Stevenson Avenue Alexandria, VArrr. . www.counseling.org

Herbert, J,. \& Lorenz, D,. \& Trusty, J.( $(\cdot \cdot \cdot)$.Career Assessment Practices for High School Students with Disabilities and Perceived Value Reported by Transition Personnel, Journal of Rehabilitation, VT(\&), IN-YT.

Iswari, M. $(r \cdot \mid \vee)$. Career guidance model in independence of deaf children in time after special senior high school. Journal of ICSAR, ' $\left.(r), 1 \mu I_{-}\right) \mathrm{rr}$. Jankute,M \&Baranauskiene,I.( $(Y, Y)$ ).Vocational counseling of Students with Special Education Needs from The Viewpoint of Principals of Mainstream school, Social Welfare Interdisciplinary Approach, $\Upsilon_{(}()$, VY_Ar.

Murugami, M.,\& Nel, N.(Y.|r).A developmental career guidance and Counselling process for learners with disabilities: preparation for employment, International Research journals, $r(\varepsilon), r q r-r v \cdot$ 
Schley, S., \& Wlater, G., \& Weathers, R., \& Hemmeter, J.,\& Hennessey, J., \& Smith, D. $\left(\Gamma_{\cdots} \cdot \mathrm{V}\right)$. Introduction to special education.Boston:Allyn and Bacon.

Stewart, A. $(\uparrow \cdots 0)$. A Comparison of Career Counseling Provided by master's and Doctoral Counselors, Journal of career development ,rT(1), r-10.

Stock, S., \& davies, D., \& Secor, R., \& Wehmeyer, M.( $(\cdots r)$. Selfdirected career preference selection for individuals with intellectual disabilities: Using computer technology to enhance self-determination. Journal of Vocational Rehabilitation, $\left.19(r), 90_{-}\right) \cdot r$. 